\title{
BIOCLIMATOLOGIA APLICADA A ARQUITETURA: ESTRATÉGIAS BIOCLIMÁTICAS EM UM PROJETO ARQUITETÔNICO PARA A CIDADE DE ATIBAIA - SP
}

\section{ARTIGO ORIGINAL}

ZIMBRES, Roberto Forghieri Vernalha ${ }^{1}$

THIEMANN, Flávia Torreão Corrêa da Silva ${ }^{2}$

ZIMBRES, Roberto Forghieri Vernalha. THIEMANN, Flávia Torreão Corrêa da Silva. Bioclimatologia aplicada a arquitetura: Estratégias bioclimáticas em um projeto arquitetônico para a Cidade de Atibaia - SP. Revista Científica Multidisciplinar Núcleo do Conhecimento. Ano 05, Ed. 06, Vol. 10, pp. 73-103. Junho de 2020. ISSN: 2448-0959, Link de

acesso: https://www.nucleodoconhecimento.com.br/arquitetura/bioclimatologia

\section{RESUMO}

O presente estudo trata de estratégias bioclimáticas em um projeto arquitetônico voltado para a cidade de Atibaia em um terreno na zona rural no bairro da Cachoeira localizado entre uma mata atlântica fechada e no alto da montanha, proporcionando uma excelente vista. Buscou-se estudar a caracterização do clima de Atibaia aplicando a norma NBR 15220-3 e através do levantamento de dados do software ZBBR, detalhando deste modo, as estratégias bioclimáticas para o verão e inverno. A cidade de Atibaia possui as quatro estações bem definidas, com um verão quente e chuvoso e um inverno relativamente frio e seco, tornando assim, um grande desafio

1 Especialista em Gestão Urbana e Sustentabilidade, Especialista em Sustentabilidade na Construção Civil, Graduado em Arquitetura e Urbanismo pela Universidade Estadual do Maranhão.

2 Doutorado em Ecologia e Recursos Naturais. Mestrado em Biologia Parasitária. Graduação em Ciências Biológicas. 
na realização de um anteprojeto. Neste caso, o anteprojeto se torna necessário para que o usuário tenha conforto dentro de uma edificação em todo o período do ano. Para a elaboração deste trabalho, foi escolhida uma abordagem de pesquisa aplicada, contribuindo para fins práticos, transformando em ação concreta os resultados do trabalho. Deste modo, o procedimento metodológico foi feito através da Pesquisa (Estudo de diretrizes indicadas pela NBR 15220-3 e aplicação dos softwares), Análise (Análise do terreno em relação a todo o embasamento da pesquisa), e por fim, a realização do Anteprojeto (Elaboração do Anteprojeto).

Palavras Chave: Anteprojeto, Atibaia, bioclimáticas, estratégias, NBR 15220-3.

\section{INTRODUÇÃO}

Hoje em dia, determinados ecossistemas da Terra, estão altamente danificados. As atividades humanas estão cada vez mais aumentando, e deixando estes ecossistemas em estado crítico. A construção civil tem grande responsabilidade, pois, utiliza-se de grande matéria prima, energia, liberação de emissões de gases de efeito estufa e gera uma quantidade significativa de resíduos sólidos. As pessoas passam $90 \%$ do seu tempo dentro de edificações, consequentemente, estes ambientes internos precisam estar saudáveis e confortáveis para contribuir na saúde e bem estar das mesmas.

Através dos anos os projetos arquitetônicos foram evoluindo, soluções novas foram criadas e com o passar dos anos, as construções estão ficando mais ecológicas mais sustentáveis. A forma da casa, o impacto dos materiais da edificação no meio ambiente, o uso da ventilação e da luz natural, a eficiência energética, o uso inteligente da água em uma edificação, as coberturas e os selos verdes, todas estas características e elementos, fazem parte destes estudos e evolução da sustentabilidade.

No entanto, o estudo do clima de determinada região, se tornou essencial para que qualquer projeto de uma edificação tenha um conforto ambiental, fornecendo assim, este estudo, informações básicas à construção do programa de necessidades. 
Através das informações obtidas pela as variáveis climáticas, pode-se chegar a um resultado de conforto do espaço arquitetônico construído.

Nos dias de hoje temos o desafio de deixar qualquer edificação, em qualquer época do ano, confortável e agradável. Muitos usuários reclamam de suas moradias tanto no verão quanto no inverno. É papel fundamental do profissional de arquitetura ou engenharia, pensar, planejar e proporcionar este problema em solução.

O presente estudo teve como objetivo principal, estudar as estratégias bioclimáticas em um projeto arquitetônico voltado a cidade de Atibaia. Através deste estudo, uma casa especificamente, em um terreno no bairro da cachoeira em Atibaia, terá conforto térmico no período do ano inteiro, trazendo bem estar a este usuário/morador.

Deste modo, será caracterizado o clima de Atibaia segundo Köppen-Geiger, aplicando em seguida a norma NBR 15220-3 quanto às regiões bioclimáticas, e por fim, apresentado as estratégias bioclimáticas e recomendações em um anteprojeto. Curiosamente a cidade de Atibaia, foi eleita em 2009 pela Organização das Nações Unidas para a Educação, a Ciência e a Cultura (Unesco), o segundo melhor clima do mundo, fazendo com que, aumente o desafio, pois as quatro estações do ano estão bem definidas.

\section{OBJETIVOS}

O presente estudo teve como objetivo principal, estudar as estratégias bioclimáticas em um anteprojeto arquitetônico voltado a cidade de Atibaia no bairro da Cachoeira, em meio à mata atlântica fechada na zona rural da cidade. Este trabalho pretende analisar a caracterização climática do local e o estudo das diretrizes indicadas pela norma brasileira "NBR 15220-3: Desempenho térmico de edificações" (ABNT, 2005) junto ao software ZBBR (Zoneamento Bioclimático Brasileiro), aplicando as estratégias em um anteprojeto arquitetônico para trazer conforto ao seu usuário. 


\section{METODOLOGIA}

Para desenvolvimento do presente trabalho foram obedecidas as seguintes etapas: caracterização climática de Atibaia; pesquisa bibliográfica através de análise de livros, artigos científicos e dissertações de mestrado. Aplicação da Norma NBR 15220-3 (levantamento das estratégias bioclimáticas indicadas e comparação com as estratégias indicadas pelo programa ZBBR); detalhamento das estratégias e aplicação das mesmas em um anteprojeto localizado na cidade de Atibaia.

\subsection{CARACTERIZAÇÕES CLIMÁTICA DE ATIBAIA}

A caracterização climática de Atibaia foi embasada na classificação climática de Köppen-Geiger.

O sistema de classificação climática mais utilizada na climatologia, ecologia e geografia é o de Köppen-Geiger, que é uma classificação genérica, lançado pela primeira vez em 1900, onde Köppen relacionava o clima com a vegetação, a partir de critérios numéricos que definiriam os tipos climáticos, porém em algumas ocasiões esta classificação não apresenta parâmetros para distinguir quanto às regiões e biomas distintos. Segundo Ayoade (1996), este primeiro modelo baseava-se nas zonas de vegetação do mapa de vegetação feito por Alphonse de Candolle. O modelo foi revisado em 1918, dando maior atenção à temperatura, à precipitação pluvial e às suas características sazonais.[3]

Também foram consultados dados climatológicos de Atibaia fornecidos pela Empresa Brasileira de Pesquisa de Agropecuária (Embrapa), pelo Centro de Pesquisas Meteorológicas e Climáticas Aplicadas à Agricultura (CEPAGRI) e pelo Laboratório de Eficiência Energética em Edificações (labEEE). 


\subsection{APLICAÇÃO DA NORMA NBR 15220-3}

O Brasil está dividido em oito regiões bioclimáticas diferentes segundo a "NBR 152203: Desempenho térmico de edificações" (Figura 1). Para cada uma das regiões há um conjunto de recomendações técnico-construtivas, otimizando assim, o desempenho das edificações. A cidade de Atibaia está inserida na Zona Bioclimática 3 (Figura 2).

Figura 1 - Zoneamento Bioclimático Brasileiro.

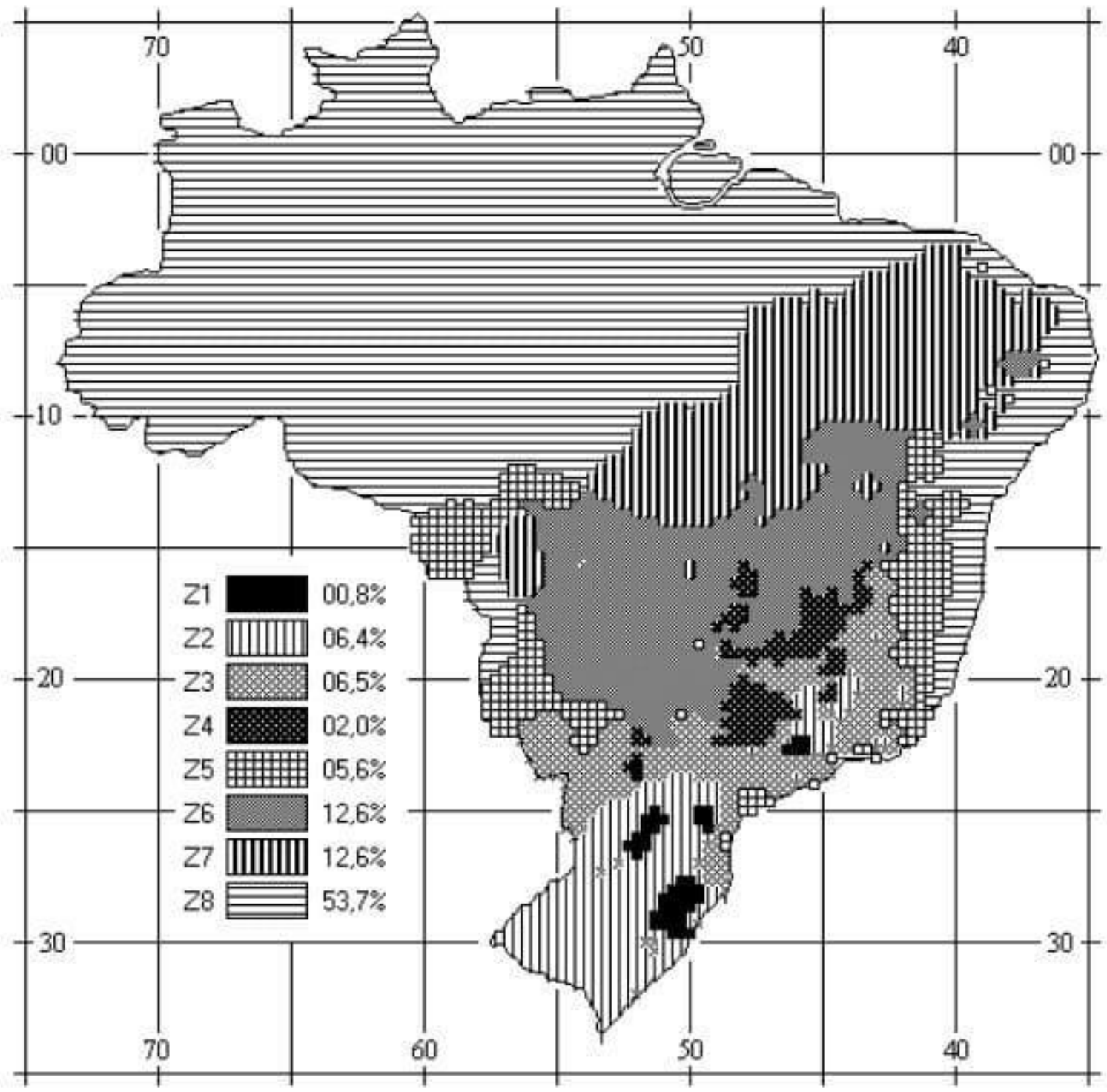

Fonte: NBR 15220-3 (ABNT, 2005). 
Figura 2 - Localização da zona bioclimática 3 no mapa do Brasil.

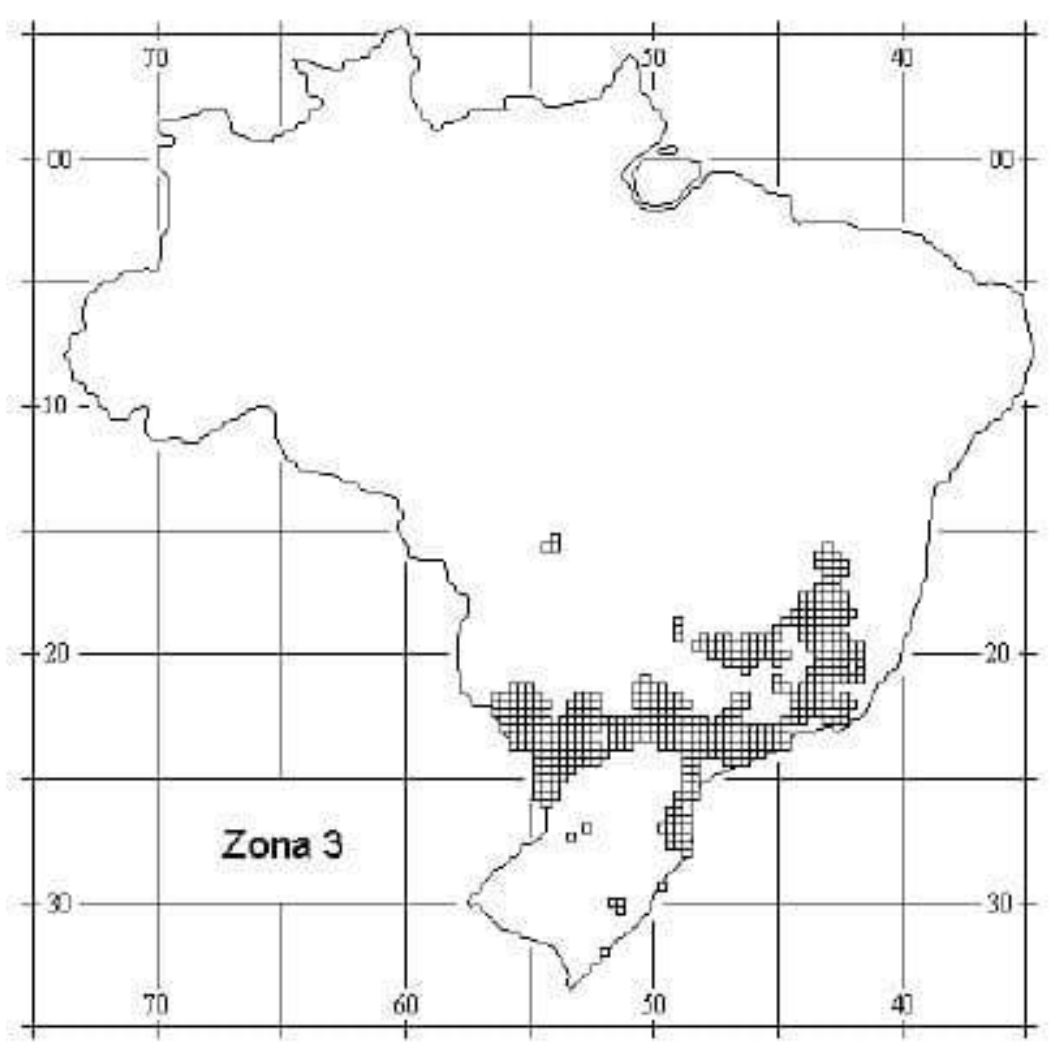

Fonte: NBR 15220-3 (ABNT, 2005).

\subsection{DETALHAMENTO DAS ESTRATÉGIAS E APLICAÇÃO DAS MESMAS EM UM ANTEPROJETO LOCALIZADO NA CIDADE DE ATIBAIA}

Para a elaboração deste trabalho, foi optado por uma abordagem de pesquisa aplicada, contribuindo para fins práticos, transformando em ação concreta os resultados do trabalho. Através da análise do terreno em relação com todo o embasamento da pesquisa e coleta de dados, as estratégias foram traçadas para a realização do Anteprojeto arquitetônico na cidade de Atibaia - SP. 


\section{RESULTADOS E DISCUSSÃO}

\subsection{ESTRATÉGIAS BIOCLIMÁTICAS EM UM ANTEPROJETO ARQUITETÔNICO NA CIDADE DE ATIBAIA-SP}

\subsubsection{CARACTERIZAÇÃO CLIMÁTICA DE ATIBAIA}

A cidade de Atibaia encontra-se na latitude de $23^{\circ}, 12^{\prime}$ sul e longitude de $46^{\circ}, 55^{\prime}$ oeste a 800 metros de Altitude. A classificação climática de Atibaia foi realizada com base na classificação climática de Köppen-Geiger e foram também consultados dados climatológicos da cidade de Atibaia fornecidos pela Empresa Brasileira de Pesquisa de Agropecuária (Embrapa) e pelo Centro de Pesquisas Meteorológicas e Climáticas Aplicadas à Agricultura (CEPAGRI).

O clima de Atibaia apresenta uma temperatura média anual de $20,0^{\circ} \mathrm{C}$, sendo a mínima no mês de julho de $9,3^{\circ} \mathrm{C}$ e a máxima de $28,3^{\circ} \mathrm{C}$ no mês de janeiro e fevereiro. A pluviosidade anual é de $1510 \mathrm{~mm}$, tendo a máxima no mês de janeiro de 263,3 mm e a mínima de 34,2 mm no mês de agosto. Este padrão climático é característico do clima tipo Cwa pela classificação de Köppen (Tabela 1).

Tabela 1 - Segundo a classificação de Köppen quanto ao tipo climático CWA.

\begin{tabular}{|l|l|}
\hline & Clima temperado ou Clima temperado quente \\
& - Climas mesotérmicos \\
\hline $\mathrm{C}$ & - Temperatura média do ar dos 3 meses mais frios compreendidas entre \\
& $-3^{\circ} \mathrm{C}$ e $18^{\circ} \mathrm{C}$ \\
& - Temperatura média do mês mais quente $>10^{\circ} \mathrm{C}$ \\
& - Estações de Verão e Inverno bem definidas \\
\hline W & Chuvas de Verão \\
\hline
\end{tabular}


- verão quente

A $\quad$ Temperatura média do ar no mês mais quente $>22^{\circ} \mathrm{C}$

Fonte: Elaborada pelo autor, segundo a classificação de Köppen quanto ao tipo climático CWA, disponível em: https://portais.ufg.br/up/68/o/Classifica o_Clim_tica_Koppen.pdf. Acesso em 5 maio.

\subsubsection{APLICAÇÃO DA NORMA NBR 15220-3 PARA O CLIMA DE ATIBAIA SP}

A cidade de Atibaia está inserida na Zona Bioclimática 3, na qual as estratégias presentes foram coletadas através do programa ZBBR (conforme a ABNT NBR 15220-3, de 29/04/2005) e algumas adaptações de Lamberts e Triana (2006) da NBR 15220-3, obtendo-se assim, as diretrizes construtivas para a cidade de Atibaia-SP, conforme averígua-se na figura 3.

Figura 3 - Zoneamento Bioclimático Brasileiro e Diretrizes Construtivas para o clima de Atibaia - SP

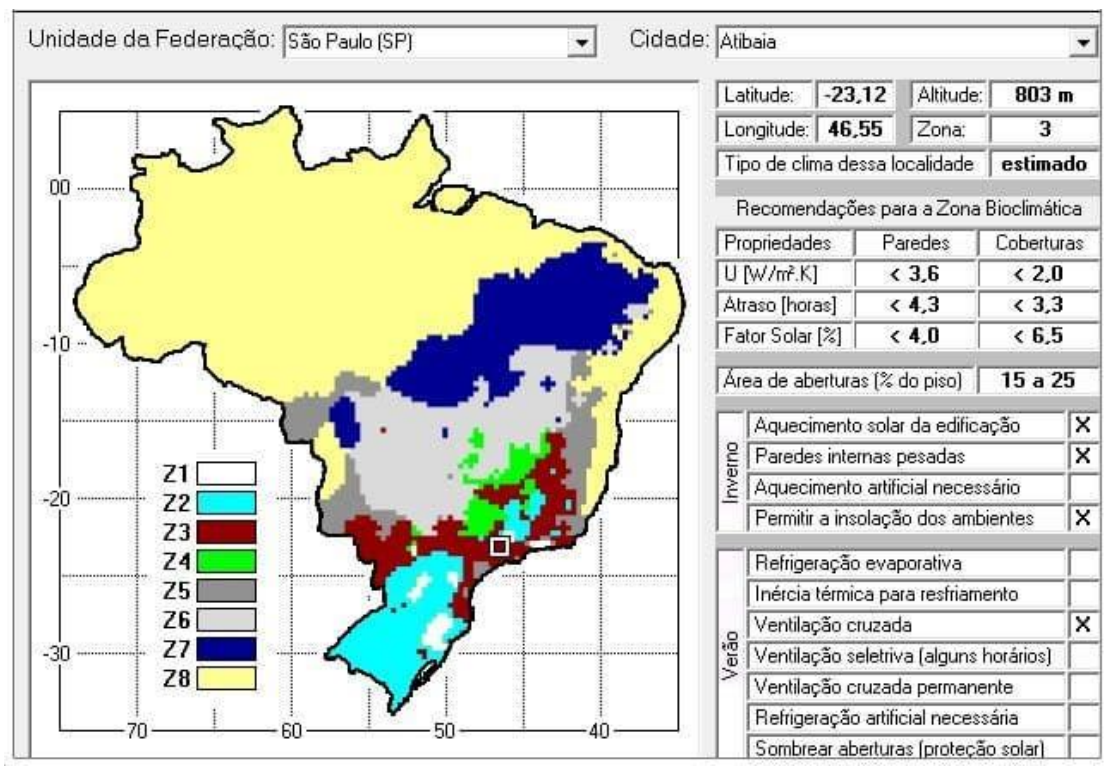

Fonte: Arquivo pessoal do autor realizado pelo Software ZBBR. 
As estratégias para um projeto alteram de acordo com o clima de cada região em que são aplicadas, mas em geral, empregam o desenho da edificação, a disposição das aberturas (portas, janelas, claraboias etc.) e o desempenho térmico dos materiais. Neste presente estudo, foram levantadas as diretrizes estabelecidas pela norma para a Zona Bioclimática 3, na qual a cidade de Atibaia está inserida. Em relação à cobertura e às paredes externas, a norma faz a indicação das propriedades dos materiais de acordo com as Tabelas 2 e 3 . O Fator de Calor Solar é determinado pela seguinte equação $\mathrm{FS}=100$. U. $\alpha$.Rse $(\%)$, onde, $U$ = transmitância, $\alpha=$ absortância, Rse $=$ resistência superficial externa .

Tabela 2 - Limites aceitáveis de indicadores do desempenho térmico de coberturas.

\begin{tabular}{|l|l|l|l|l|}
\hline Zona & $\begin{array}{l}\text { Coberturas } \\
\text { recomendadas }\end{array}$ & $\begin{array}{l}\text { Transmitância } \\
(\mathbf{U},\end{array}$ & $\begin{array}{l}\text { Atraso } \\
\text { Térmico }\end{array}$ & Fator Solar \\
\hline $\left.\mathbf{W} / \mathbf{m}^{2} . \mathbf{K}\right)$ & $\begin{array}{l}\mathbf{( \phi ) , ~ e m ~} \\
\text { horas })\end{array}$ & \\
\hline $\mathbf{3}$ & $\begin{array}{l}\text { LevS, em \%) } \\
\text { isoladas }\end{array}$ & $\mathrm{U} \leq 2,00$ & $\phi \leq 3,3$ & $\mathrm{FS} \leq 6,5$ \\
\hline
\end{tabular}

Fonte: Elaborado a partir da NBR 15220-3, adaptado de Lamberts e Triana (2006).

Tabela 3 - Limites aceitáveis de indicadores do desempenho térmico de paredes externas.

\begin{tabular}{|c|c|c|c|c|}
\hline Zona & $\begin{array}{l}\text { Paredes } \\
\text { externas } \\
\text { recomendadas }\end{array}$ & $\begin{array}{l}\text { Transmitância } \\
(U, \\
\left.W / m^{2} . K\right) \quad \text { em }\end{array}$ & $\begin{array}{l}\text { Atraso } \\
\text { Térmico } \\
(\phi, \quad \text { em } \\
\text { horas) }\end{array}$ & $\begin{array}{l}\text { Fator Solar } \\
\text { (FS, em \%) }\end{array}$ \\
\hline 3 & $\begin{array}{ll}\text { Leves } & \mathrm{e} \\
\text { refletoras } & \end{array}$ & $U \leq 3,60$ & $\phi \leq 4,3$ & $\mathrm{FS} \leq 4,0$ \\
\hline
\end{tabular}

Fonte: Elaborado a partir da NBR 15220-3, adaptado de Lamberts e Triana (2006). 
Com relação às aberturas para ventilação, a NBR 15220-3 indica as estratégias presentes na Tabela 4.

Tabela 4 - Recomendações quanto ao dimensionamento e sombreamento de aberturas.

\begin{tabular}{|l|l|l|}
\hline Zona & $\begin{array}{l}\text { Área de abertura para } \\
\text { ventilação }\end{array}$ & $\begin{array}{l}\text { Sombreamento das } \\
\text { aberturas }\end{array}$ \\
\hline $\begin{array}{l}\text { (A }=\% \text { da área do } \\
\text { piso })\end{array}$ & \\
\hline 3 & Média: $15 \%<\mathrm{A}<25 \%$ & $\begin{array}{l}\text { Permitir sol apenas } \\
\text { durante o inverno }\end{array}$ \\
\hline
\end{tabular}

Fonte: Elaborado a partir da NBR 15220-3, adaptado de Lamberts e Triana (2006).

A Tabela 5 resume as estratégias bioclimáticas para a Zona Bioclimática 3, para o Inverno e o Verão.

Tabela 5 - Estratégias bioclimáticas para a Zona Bioclimática 3, para o Inverno e o Verão.

\section{Estratégias Bioclimáticas}

\begin{tabular}{l|l} 
Inverno & Verão \\
$\begin{array}{l}\text { Estação de Aquecimento } \\
\text { a) Aquecimento solar da a) Ventilação cruzada } \\
\text { edificação }\end{array}$ \\
$\begin{array}{l}\text { b) vedações internas pesadas } \\
\text { (inércia térmica) }\end{array}$ \\
$\begin{array}{l}\text { c) Permitir a insolação dos } \\
\text { ambientes }\end{array}$
\end{tabular}


Fonte: Elaborado a partir da NBR 15220-3, adaptado de Lamberts e Triana (2006).

\subsubsection{DETALHAMENTO DAS ESTRATÉGIAS PARA O INVERNO}

\subsubsection{AQUECIMENTO SOLAR DA EDIFICAÇÃO}

Quando falamos em aquecimento solar da edificação, podemos falar em aquecimento direto e indireto. $\mathrm{O}$ ganho direto primeiramente, consiste em permitir a entrada diretamente ao interior da radiação solar através de aberturas zenitais (claraboias e domos) ou laterais (janelas e paredes transparentes). Assim que a radiação solar entra nos ambientes através dos elementos transparentes, gera-se o "efeito estufa", aquecendo assim, os ambientes internos quando necessário (figura 4).

Figura 4 - Ganho solar direto.

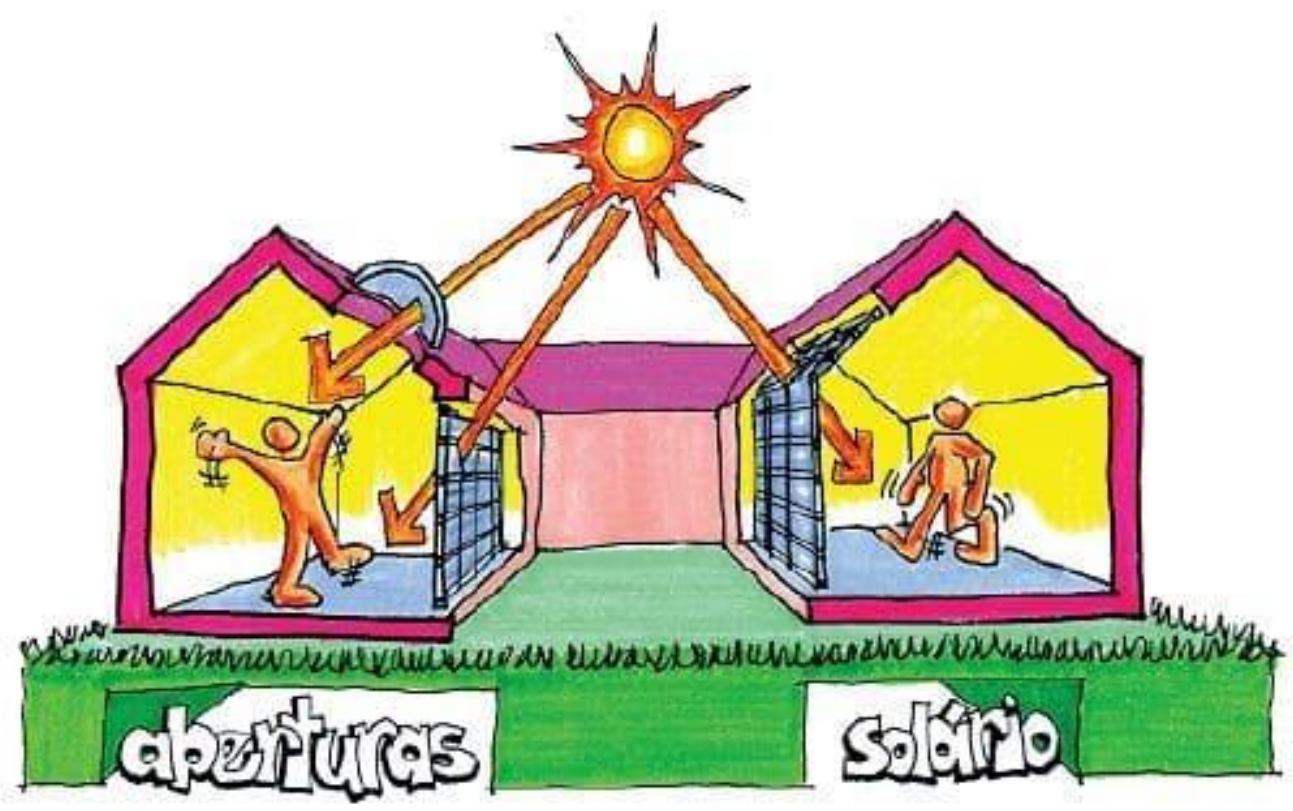

Fonte - Lamberts; Dutra; Pereira, 2004, p.276.

Quando falamos em aquecimento solar indireto, podemos citar um jardim de inverno como exemplo, captando a radiação solar e distribuindo de forma indireta aos ambientes internos. Uma outra forma de captar indiretamente estas radiações, são construir paredes de acumulação. São paredes com elevada inércia térmica expostas 
na orientação da edificação onde ficam mais expostas à insolação. Estas paredes acumulam a radiação solar, devolvendo ao ambiente mais tarde, de forma longa e por convecção. Para evitar que a parede perca o calor por convecção e por radiação para exterior, coloca-se um vidro, criando assim, uma convecção induzida pelo ar no espaço entre o vidro e a parede, conhecida como parede de trombre. $\mathrm{O}$ ar quente tende a subir, sugando assim, o ar fresco pela abertura inferior do sistema (figura 5).

Figura 5 - Ganho solar indireto.

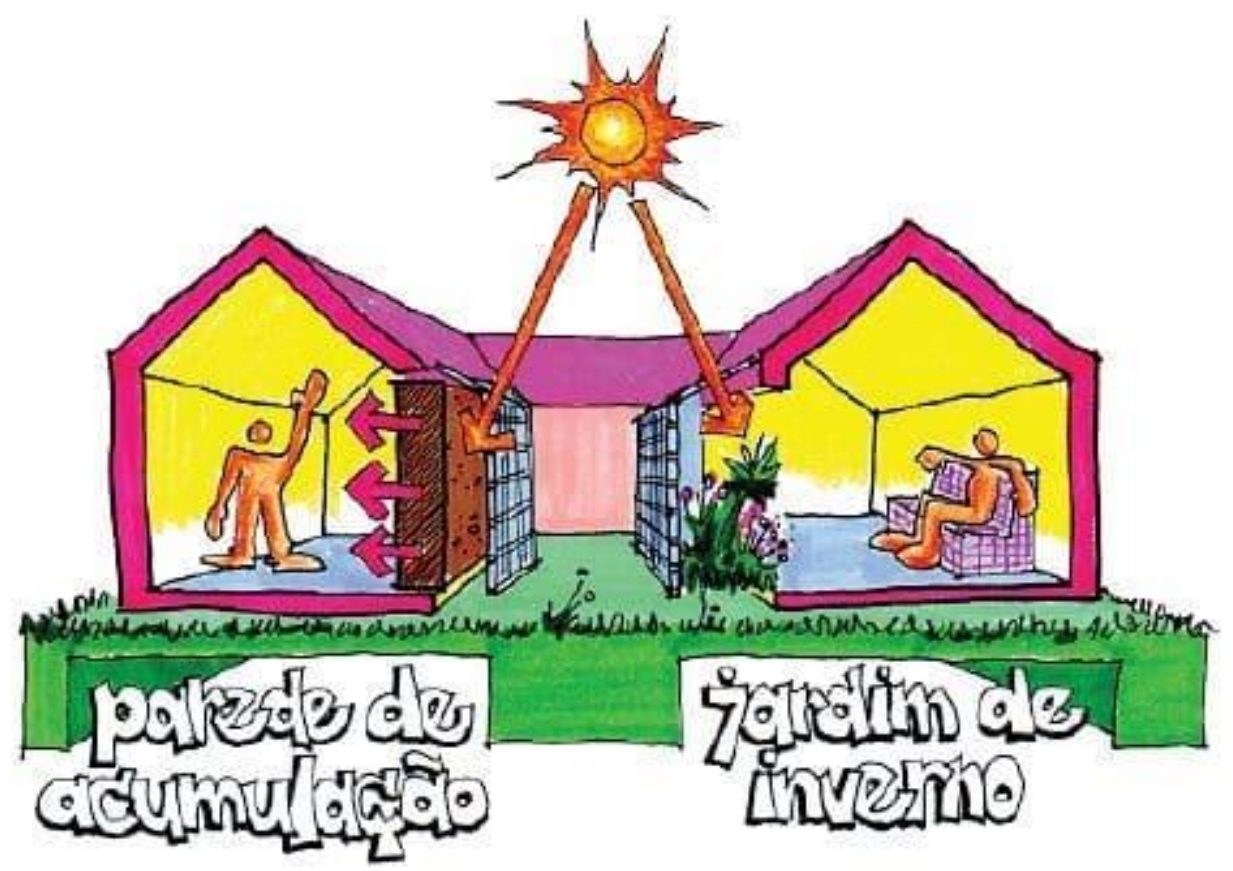

Fonte - Lamberts; Dutra; Pereira, 2004, p.276.

\subsubsection{VEDAÇÕES INTERNAS PESADAS (INÉRCIA TÉRMICA)}

Em um clima tropical de altitude, que apresenta o inverno frio e seco e o verão quente úmido, sistemas construtivos com uma inércia térmica maior, proporcionam edificações com ambientes mais confortáveis. A inércia térmica absorve o calor das paredes durante o dia, e somente à noite, devolve ao ambiente interior amenizando esta temperatura, que em invernos rigorosos, isto pode ser fundamental (figura 6). 
Figura 6 - Inércia térmica (amortecimento e retardo).

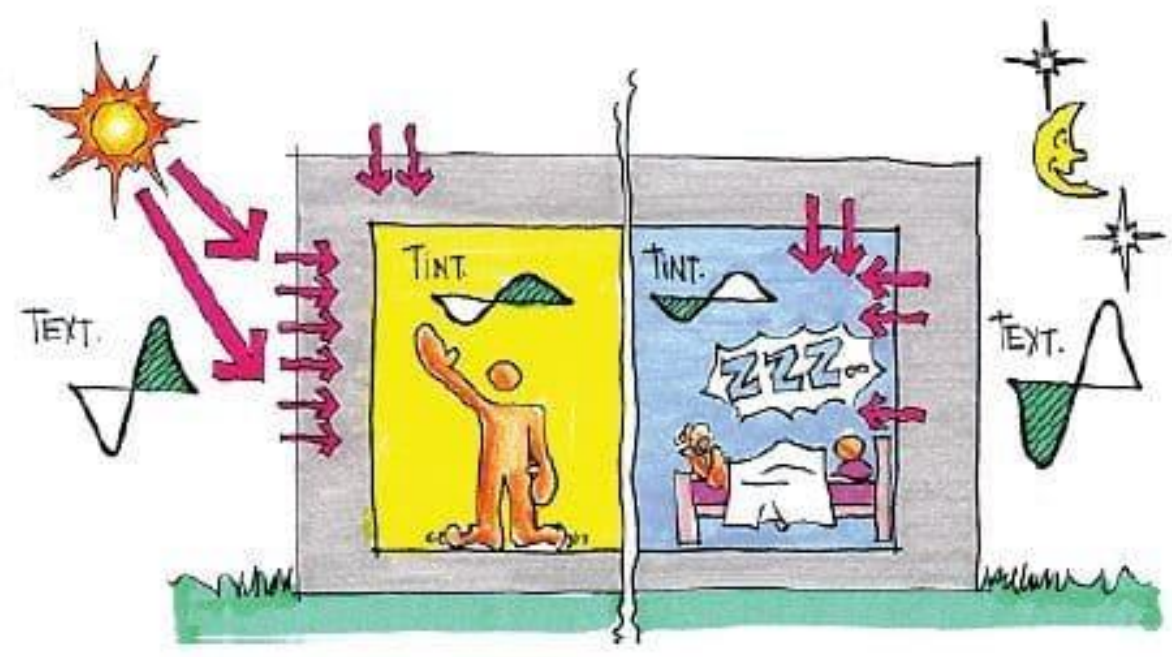

Fonte - Lamberts; Dutra; Pereira, 2004, p.198.

De acordo com a normalização, são aconselhados para Atibaia, os tipos de paredes internas conforme Tabela 6.

Tabela 6 - Transmitância térmica, capacidade térmica e atraso térmico para paredes que podem ser utilizadas em edificações no município de Atibaia - SP.

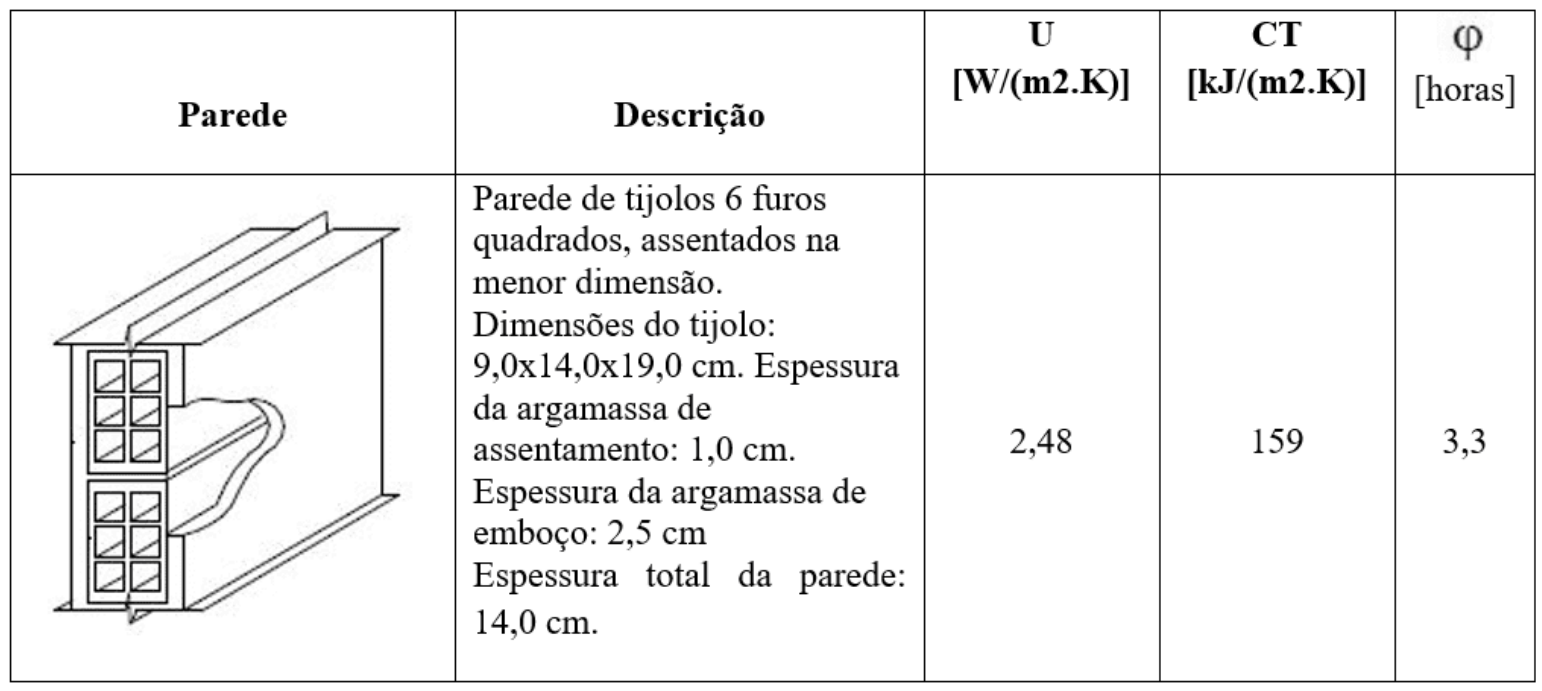




\begin{tabular}{|c|c|c|c|c|}
\hline 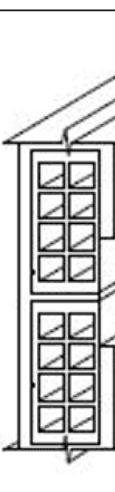 & $\begin{array}{l}\text { Parede de tijolos } 8 \text { furos } \\
\text { quadrados, assentados na } \\
\text { menor dimensão. } \\
\text { Dimensões do tijolo: } \\
\text { 9,0x19,0x19,0 cm. } \\
\text { Espessura da argamassa de } \\
\text { assentamento: } 1,0 \mathrm{~cm} \text {. } \\
\text { Espessura da argamassa de } \\
\text { emboço: } 2,5 \mathrm{~cm} . \\
\text { Espessura total da parede: } \\
14,0 \mathrm{~cm} .\end{array}$ & 2,49 & 158 & 3,3 \\
\hline 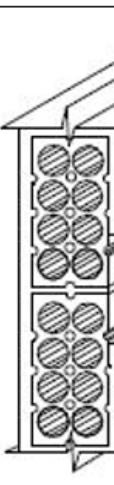 & $\begin{array}{l}\text { Parede de tijolos de } 8 \text { furos } \\
\text { circulares, assentados na } \\
\text { menor dimensão. } \\
\text { Dimensões do tijolo: } \\
\text { 10,0x20,0x20,0 cm. } \\
\text { Espessura da argamassa de } \\
\text { assentamento: } 1,0 \mathrm{~cm} \text {. } \\
\text { Espessura da argamassa de } \\
\text { emboço: } 2,5 \mathrm{~cm} . \\
\text { Espessura total da parede: } \\
15,0 \mathrm{~cm} .\end{array}$ & 2,24 & 167 & 3,7 \\
\hline
\end{tabular}

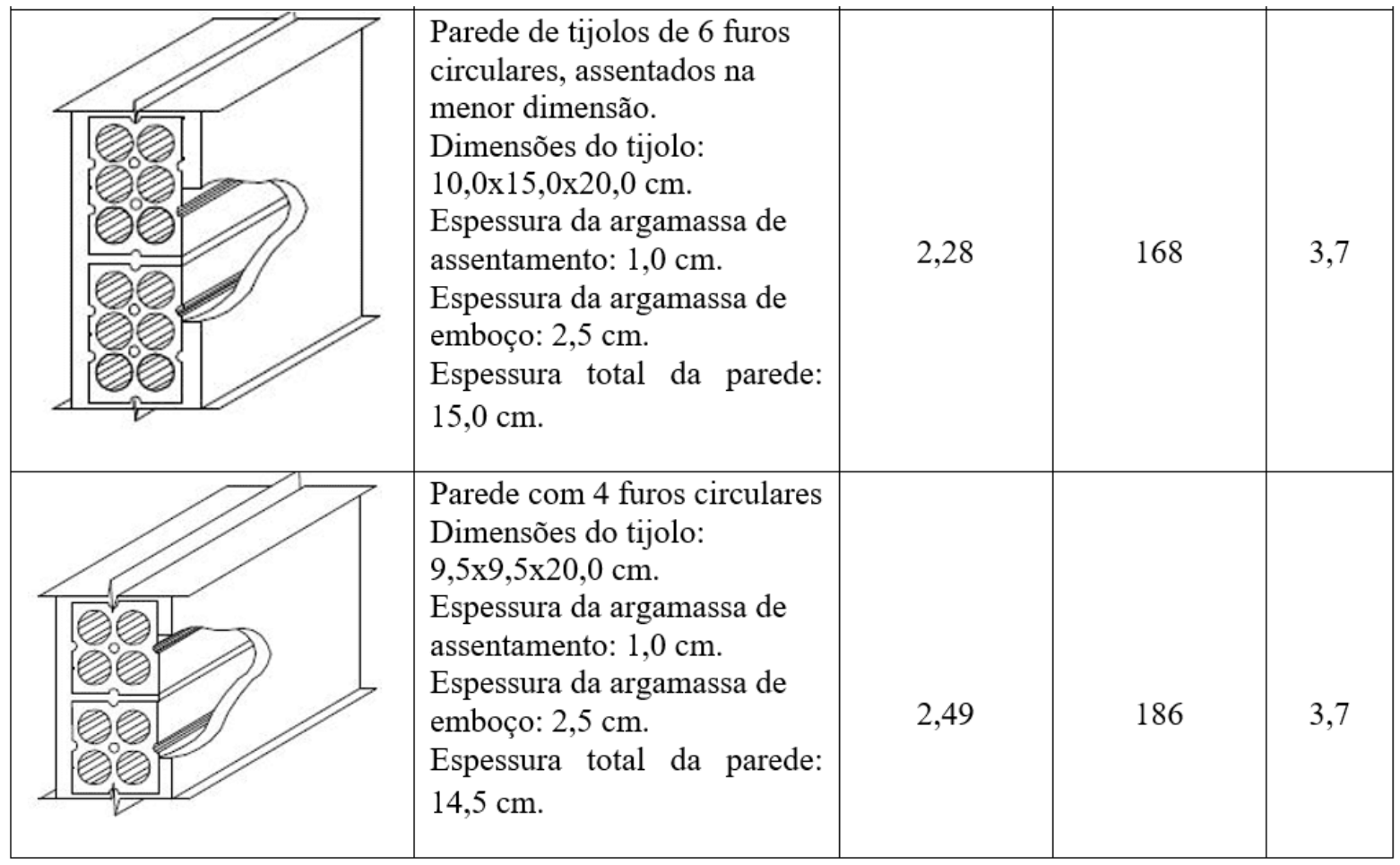




\begin{tabular}{|l|l|l|l|}
\hline & $\begin{array}{l}\text { Parede de blocos cerâmicos } \\
\text { de 3 furos. } \\
\text { Dimensões do bloco: } \\
\text { 13,0x28,0x18,5 cm. } \\
\text { Espessura da argamassa de } \\
\text { assentamento: } 1,0 \mathrm{~cm} . \\
\text { Espessura da argamassa de } \\
\text { emboço: } 2,5 \mathrm{~cm} . \\
\text { Espessura total da parede: } \\
18,0 \mathrm{~cm} .\end{array}$ & 2,43 & 3,8 \\
\hline
\end{tabular}

\begin{tabular}{|c|c|c|c|c|}
\hline & $\begin{array}{l}\text { Parede de blocos cerâmicos } \\
\text { de } 2 \text { furos. } \\
\text { Dimensões do bloco: } \\
\text { 14,0x } 29,5 \times 19,0 \mathrm{~cm} \text {. } \\
\text { Espessura da argamassa de } \\
\text { assentamento: } 1,0 \mathrm{~cm} \text {. } \\
\text { Espessura da argamassa de } \\
\text { emboço: } 2,5 \mathrm{~cm} . \\
\text { Espessura total da parede: } \\
19,0 \mathrm{~cm} .\end{array}$ & 2,45 & 203 & 4,0 \\
\hline & $\begin{array}{l}\text { Parede de tijolos com } 2 \text { furos } \\
\text { Circulares. } \\
\text { Dimensões do tijolo: } 12,5 \times 6,3 \times 22,5 \\
\mathrm{~cm} \text {. } \\
\text { Espessura da argamassa de } \\
\text { assentamento: } 1,0 \mathrm{~cm} . \\
\text { Espessura da argamassa de } \\
\text { emboço: } 2,5 \mathrm{~cm} \text {. } \\
\text { Espessura total da parede: } 17,5 \mathrm{~cm} \text {. }\end{array}$ & 2,43 & 220 & 4,2 \\
\hline 2 & $\begin{array}{l}\text { Parede de tijolos de } 6 \text { furos } \\
\text { quadrados, assentados na } \\
\text { maior dimensão. } \\
\text { Dimensões do tijolo: } \\
9,0 x 14,0 \times 19,0 \mathrm{~cm} \text {. } \\
\text { Espessura da argamassa de } \\
\text { assentamento: } 1,0 \mathrm{~cm} \text {. } \\
\text { Espessura da argamassa de } \\
\text { emboço: } 2,5 \mathrm{~cm} . \\
\text { Espessura total da parede: }\end{array}$ & 2,02 & 192 & 4,5 \\
\hline
\end{tabular}




\begin{tabular}{|c|c|c|c|c|}
\hline & $19,0 \mathrm{~cm}$. & & & \\
\hline & $\begin{array}{l}\text { Parede de tijolos de } 21 \text { furos } \\
\text { circulares, assentados na } \\
\text { menor dimensão. } \\
\text { Dimensões do tijolo: } \\
\text { 12,0x11,0x } 25,0 \mathrm{~cm} \text {. } \\
\text { Espessura da argamassa de } \\
\text { assentamento: } 1,0 \mathrm{~cm} \text {. } \\
\text { Espessura da argamassa de } \\
\text { emboço: } 2,5 \mathrm{~cm} . \\
\text { Espessura total da parede: } \\
17,0 \mathrm{~cm} .\end{array}$ & 2,31 & 227 & 4,5 \\
\hline
\end{tabular}

Fonte: Arquivo pessoal do autor elaborado a partir da NBR 15220-3 (ABNT,2005).

\subsubsection{PERMITIR INSOLAÇÃO DOS AMBIENTES}

No Brasil, maior parte do território tem verões quentes e muito sol ao longo do ano, sendo assim, tendo o sombreamento como principal estratégia bioclimática indicada. A tabela 7 mostra a necessidade de sombreamento e de insolação na cidade de Atibaia - SP, segundo a Carta Bioclimática gerada pelo programa Analysis-BIO.

Tabela 7 - Percentual de necessidades de sombreamento no município de Atibaia SP.

\begin{tabular}{|l|l|l|}
\hline Cidade & $\begin{array}{l}\text { Necessidade de sombreamento } \\
\text { (\% das horas do ano no período } \\
\text { diurno) }\end{array}$ & $\begin{array}{l}\text { Necessidade de sol (\% das horas do } \\
\text { ano no período diurno) }\end{array}$ \\
\hline Atibaia & 51,1 & 42,8 \\
\hline
\end{tabular}

Fonte: Arquivo pessoal do autor elaborado a partir do software Analysis-BIO.

Nas cidades do sudeste e sul, onde o inverno é mais frio, o sol passa ser uma fonte de calor importante. Na cidade de Atibaia, percebe-se as horas diurnas onde o sol é desejável no períodos mais frios, como o inverno, os valores são semelhantes às horas diurnas onde o sombreamento é desejável nos períodos quentes como verão. 
Importante ressaltar, que além de calor, o sol traz também a luz natural para o interior do ambiente, fator importantíssimo na arquitetura bioclimática. Sendo assim, precisase de conhecimentos precisos para sombreá-los no momentos indesejáveis (calor do verão), não sombreá-los nos momentos desejáveis (frio do inverno) e na simples necessidade de iluminação natural. O arquiteto Le Corbusier (2000) dizia que é missão da arquitetura moderna se preocupar com o sol e que o sol é nosso amigo em parte do ano, e nosso inimigo na outra parte.

Alguns conceitos de geometria solar são necessários para que não seja construídos fachadas com extrema exposição ao sol sem sombreamento como brises e qualquer outra técnica de proteção solar em períodos indesejáveis do ano. No brasil, a arquitetura deveria adaptar-se às necessidades de sombreamento e de acesso solar nos períodos mais quentes e frios, da qual, isso não vem acontecendo. A figura 7 mostra como ler a informações de uma carta solar e a figura 8 mostram as trajetórias solares no período de todo o ano.

Figura 7 - leitura da carta solar.

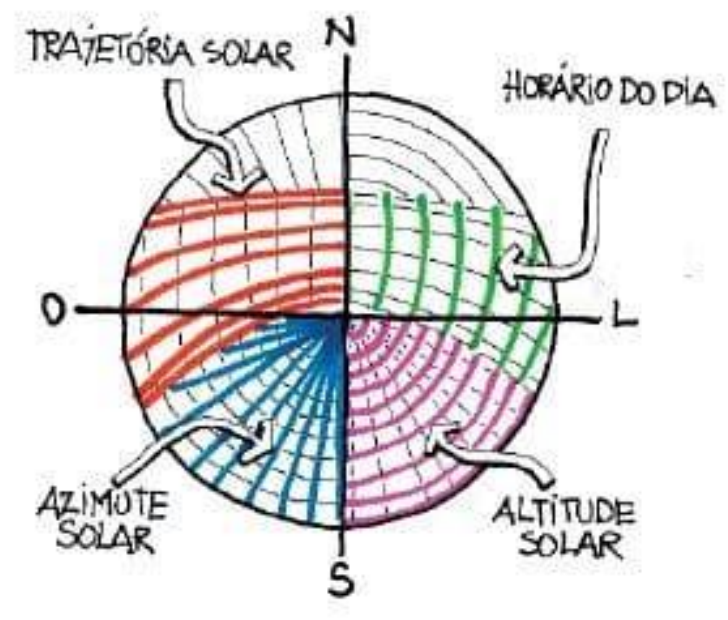

Fonte - Lamberts; Dutra; Pereira, 2004, p.123. 
Figura 8 - trajetórias solares durante todo o ano.

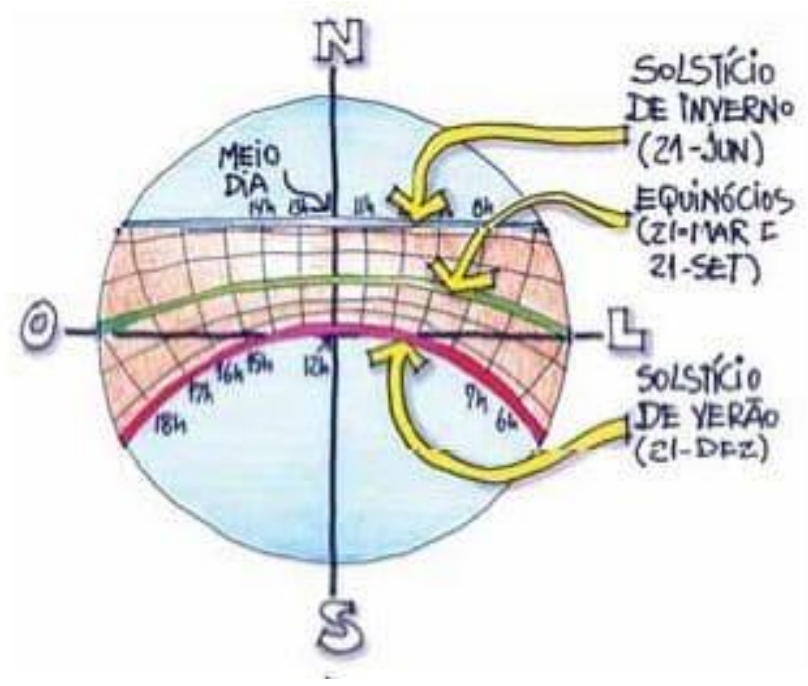

Fonte - Lamberts; Dutra; Pereira, 2004, p.123.

Através do programa Analysis-BIO, foi gerada uma Carta Bioclimática para a cidade de São Paulo, da qual pode ser reutilizada para a cidade de Atibaia, pois ambas as cidades se encontram na mesma zona bioclimática 3 definida por Köppen-Geiger. Foram desenvolvidas duas cartas solares, uma para o período de 21 de junho a 21 de dezembro (figura 9) e a outra do período de 21 de dezembro a 21 de junho (figura 10).

Figura 9 - Manchas de temperaturas para São paulo de 21 de junho até 21 de dezembro.

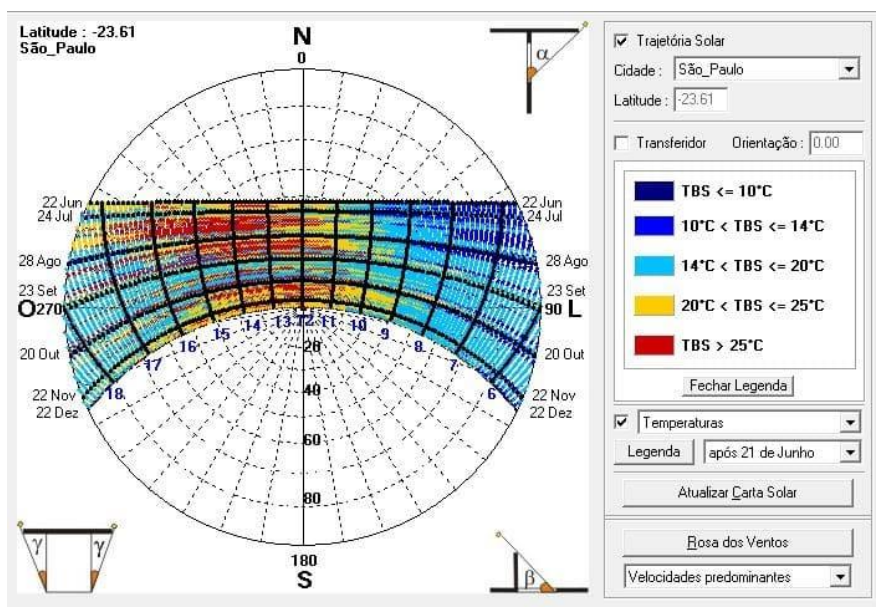

Fonte - Arquivo pessoal do autor elaborado a partir do software Analysis-BIO. 
Figura 10 - Manchas de temperaturas para São paulo de 21 de dezembro até 21 de junho.
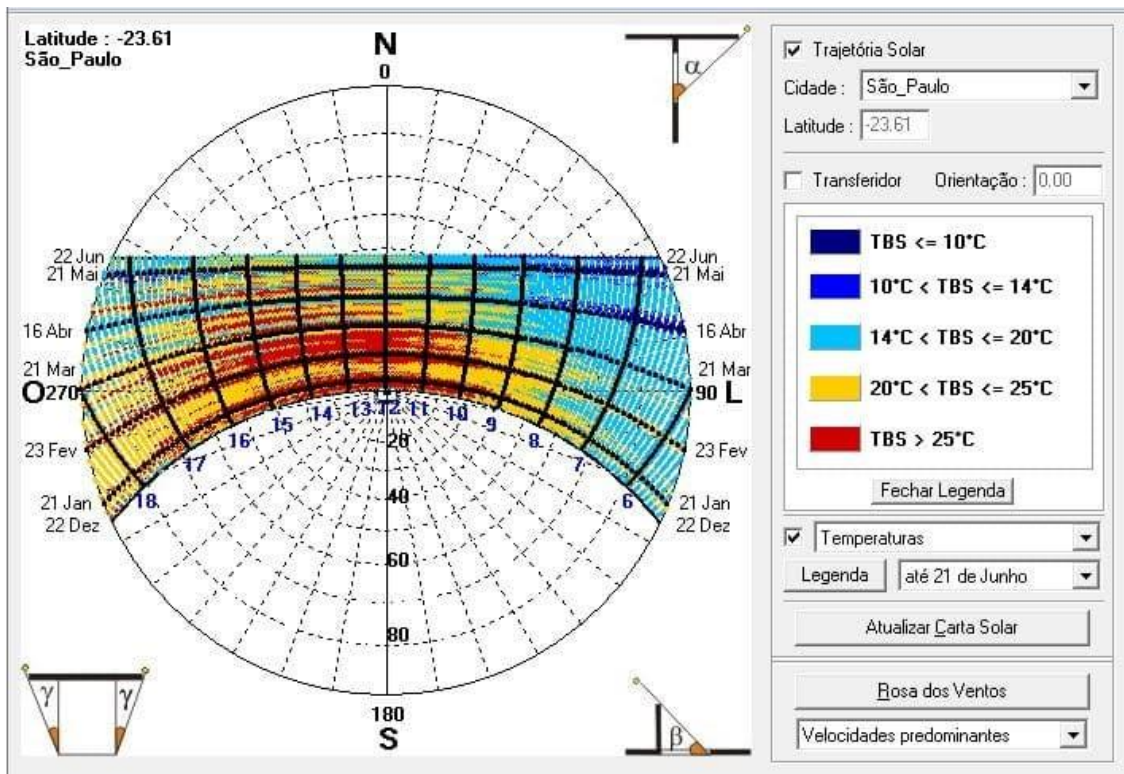

Fonte - Arquivo pessoal do autor elaborado a partir do software Analysis-BIO.

Deste modo, após a realização destas duas cartas solares, o sol indesejável comum aos dois períodos mais quentes, deve-se ter soluções de brises com partes fixas. Deve-se ter brises com partes móveis para sombrear o sol indesejável do período mais quente quando necessário, podendo remover no período mais frio quando não será mais exigido.

\subsubsection{DETALHAMENTO DAS ESTRATÉGIAS PARA O VERÃO}

\subsubsection{VENTILAÇÃO CRUZADA}

A ventilação cruzada é uma técnica muito eficaz em um ambiente interno, através de duas aberturas em paredes diferentes, conjuntamente com o conhecimento da orientação dos ventos desejáveis nos períodos quentes, tem-se um ambiente fresco em dias quentes. A figura 11 ilustra diversas maneiras de posicionamento de aberturas em diferentes paredes, estudo feito através em simulação em túnel de vento (Evans e Schiller 1988). No esquema 1 e 2 da figura, consegue maior velocidade da ventilação do ambiente, e nos esquemas 3 e 4, através de aberturas em paredes 
adjacentes, gera uma ventilação mais efetiva. O esquema 6 mostra que as aberturas muito próximas não ocasiona uma boa ventilação, afastando assim, as aberturas como mostra no esquema 5 , a distribuição dos ventos tem um resultado melhor.

Figura 11 - Padrão da ventilação determinado pelo posicionamento das aberturas, adaptado de Evans e Schiller 1988.
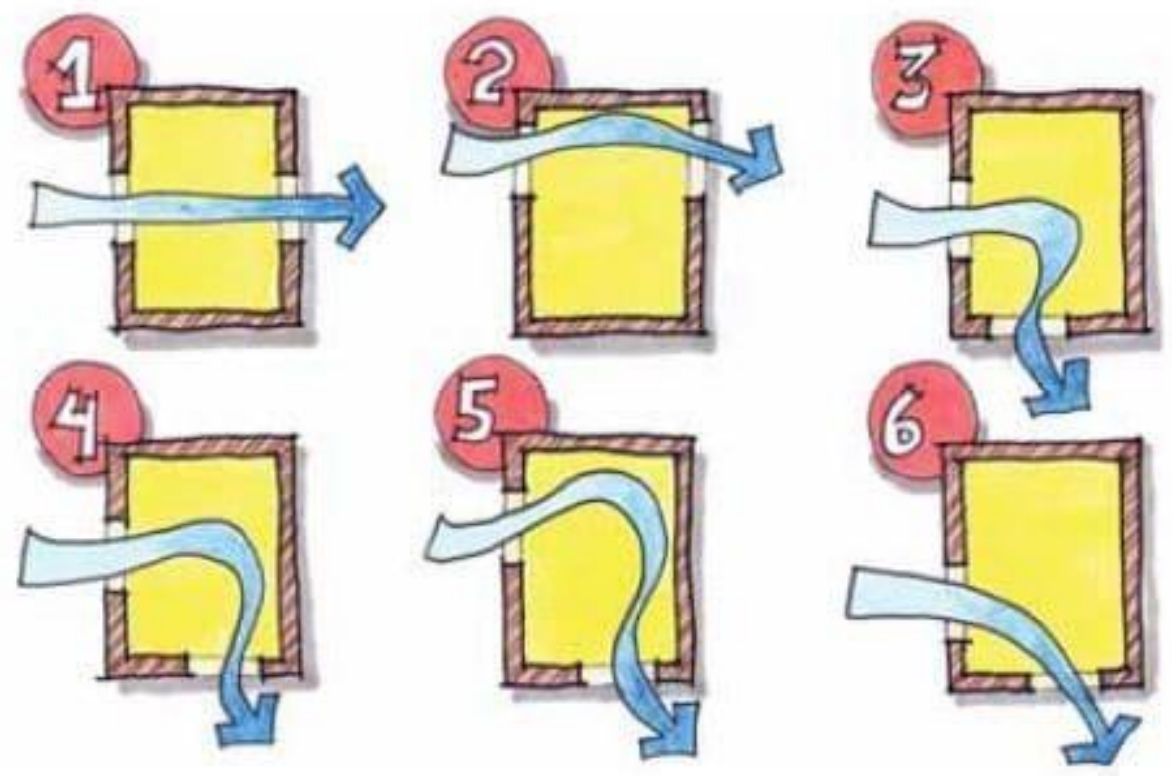

Fonte - Lamberts; Dutra; Pereira, 2004, p.185.

$\mathrm{Na}$ figura 12, os esquemas 1 e 3 , são semelhantes, porém no esquema 3 e menos eficaz, pois existe um canto com o ar estagnado. No esquema 2, a divisão do ambiente, faz com que a ventilação fique reduzida e consequentemente reduzindo também o resfriamento do ambiente. $O$ esquema 4 mostra que mesmo dividindo o ambiente, pode-se ter uma ventilação adequada ao plano de necessidades de resfriamento. No esquema 5 , a divisão faz com que um dos lados do ambiente fique sem ventilação. Por fim, no esquema 6 , através da divisão planejada faz com que diminua a ventilação em um determinado ambiente da qual precisaria realmente ser mais amena. 
Figura 12 - Estudo da ventilação em ambientes em função da presença de divisores e repartições internas, adaptado de Watson e Labs 1983.
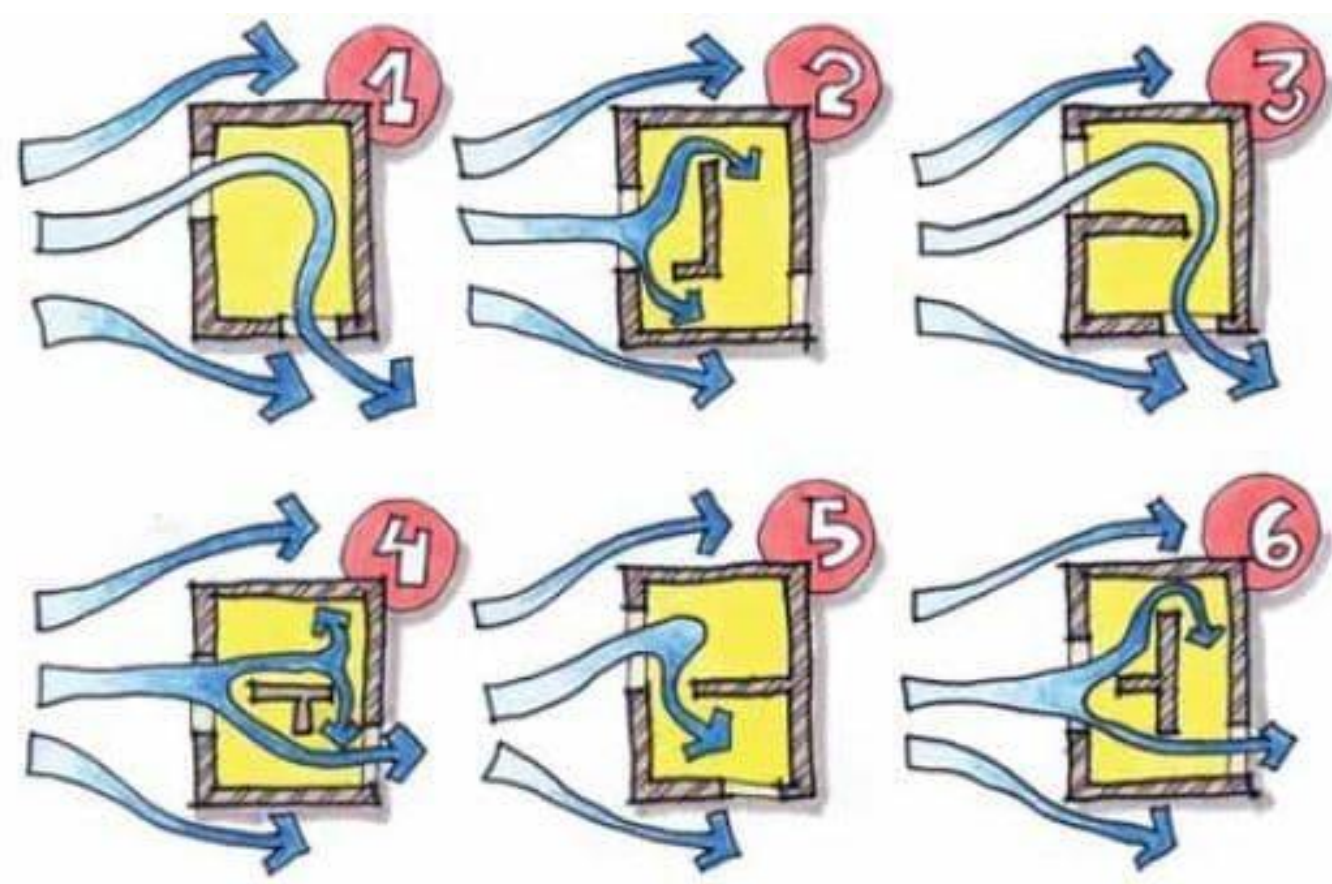

Fonte - Lamberts; Dutra; Pereira, 2004, p.185.

\subsection{APLICAÇÃO DAS ESTRATÉGIAS BIOCLIMÁTICAS EM UM ANTEPROJETO ARQUITETÔNICO NA CIDADE DE ATIBAIA-SP}

\subsubsection{TERRENO DO ANTEPROJETO}

O terreno (Figura 13) proposto para a implantação deste anteprojeto se encontra no bairro da Cachoeira. Está localizado na Área Rural NE - AR 1 (Figura 14), segundo o Plano Diretor da Cidade. 
Figura 13 - Situação do terreno (vista aérea).

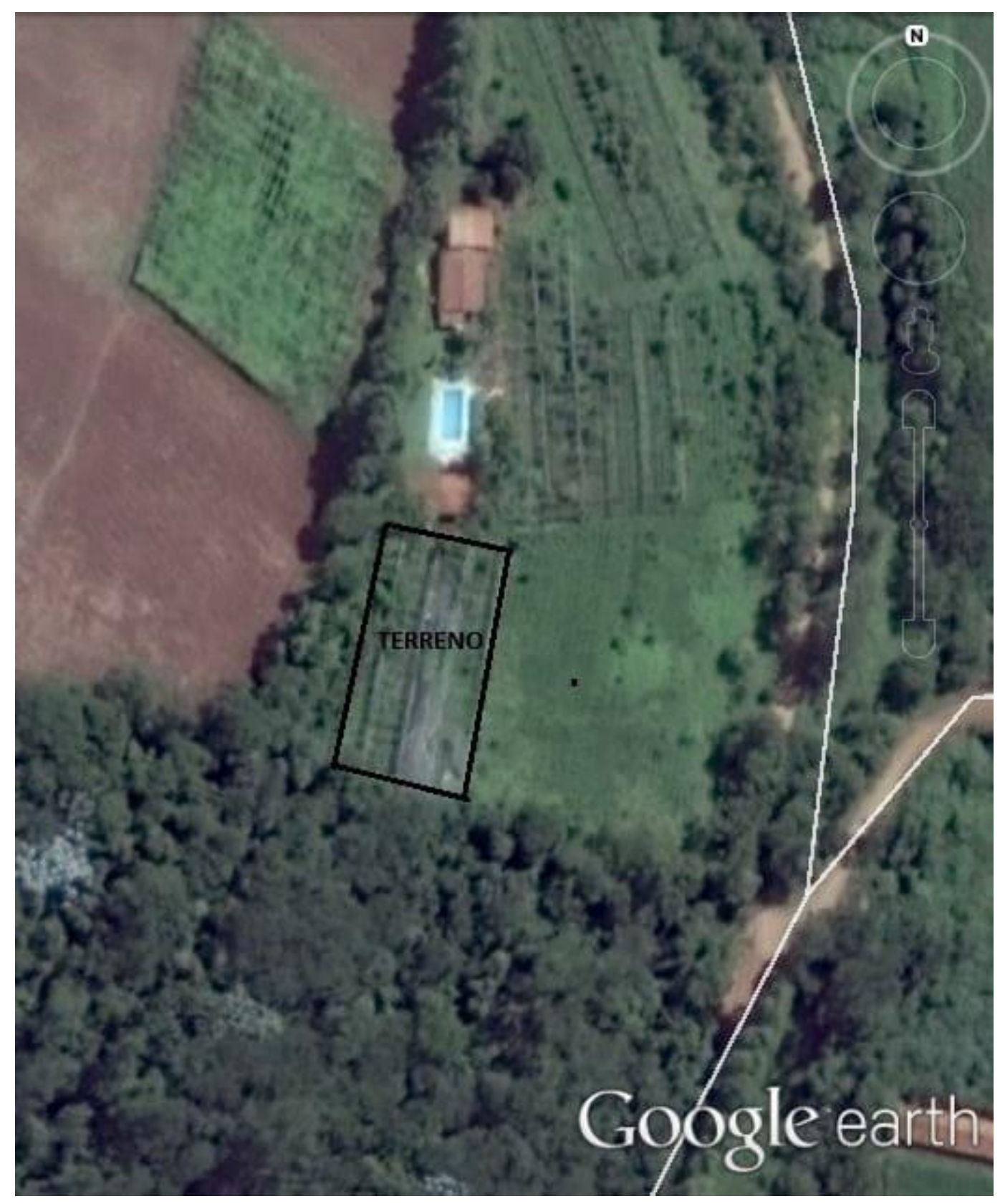

Fonte - Imagem do autor elaborada com o software Google Earth 
Figura 14 - Localização do terreno no mapa de zoneamento.

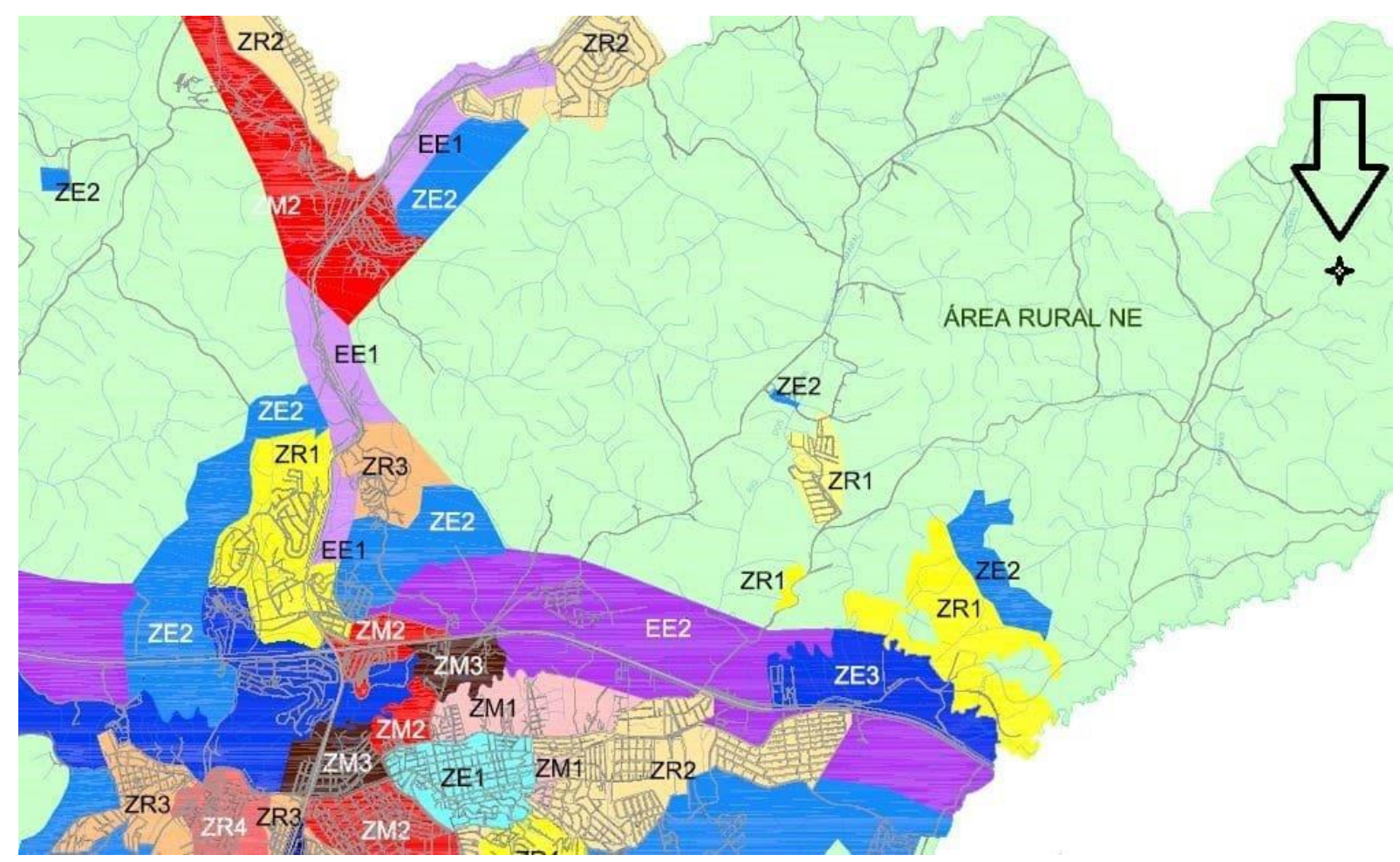

Fonte - Disponível em: http://www.atibaia.sp.gov.br/. Acesso em 01 maio.

O terreno tem dimensões de $40 \times 25$ metros e apresenta um leve declive no sentido sudeste, não apresentando qualquer edificação e possui muita vegetação principalmente nos lados sul, sudoeste e oeste, fazendo assim com que tenha um grande contato com a natureza. O terreno se encontra em uma ótima localização no alto da montanha (figura 15), fazendo com que tenha uma ótima vista no sentido leste (figura 16). 


\section{MULTIDISCIPLINARY SCIENTIFIC JOURNAL REVISTA CIENTÍFICA MULTIDISCIPLINAR NÚCLEO DO NC $\mathrm{NU}^{\prime} \mathrm{CL} \mathrm{E} O \mathrm{DO}$ conhecimento ISSN: 2448-0959 \\ CONHECIMENTO https://www.nucleodoconhecimento.com.br}

Figura 15 - Relevo do terreno.

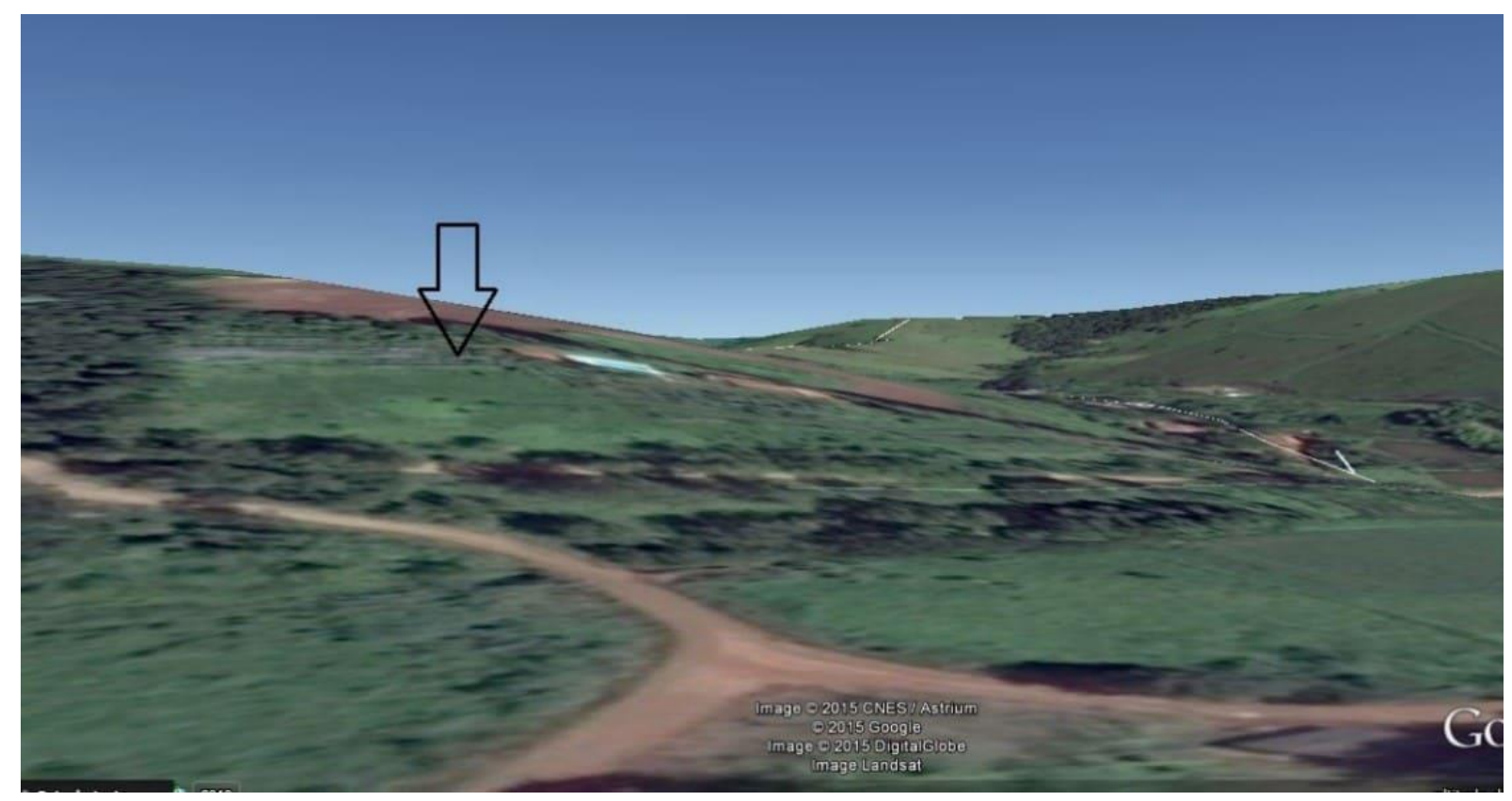

Fonte - Imagem do autor elaborada com o software Google Earth.

Figura 16 - Vista leste.

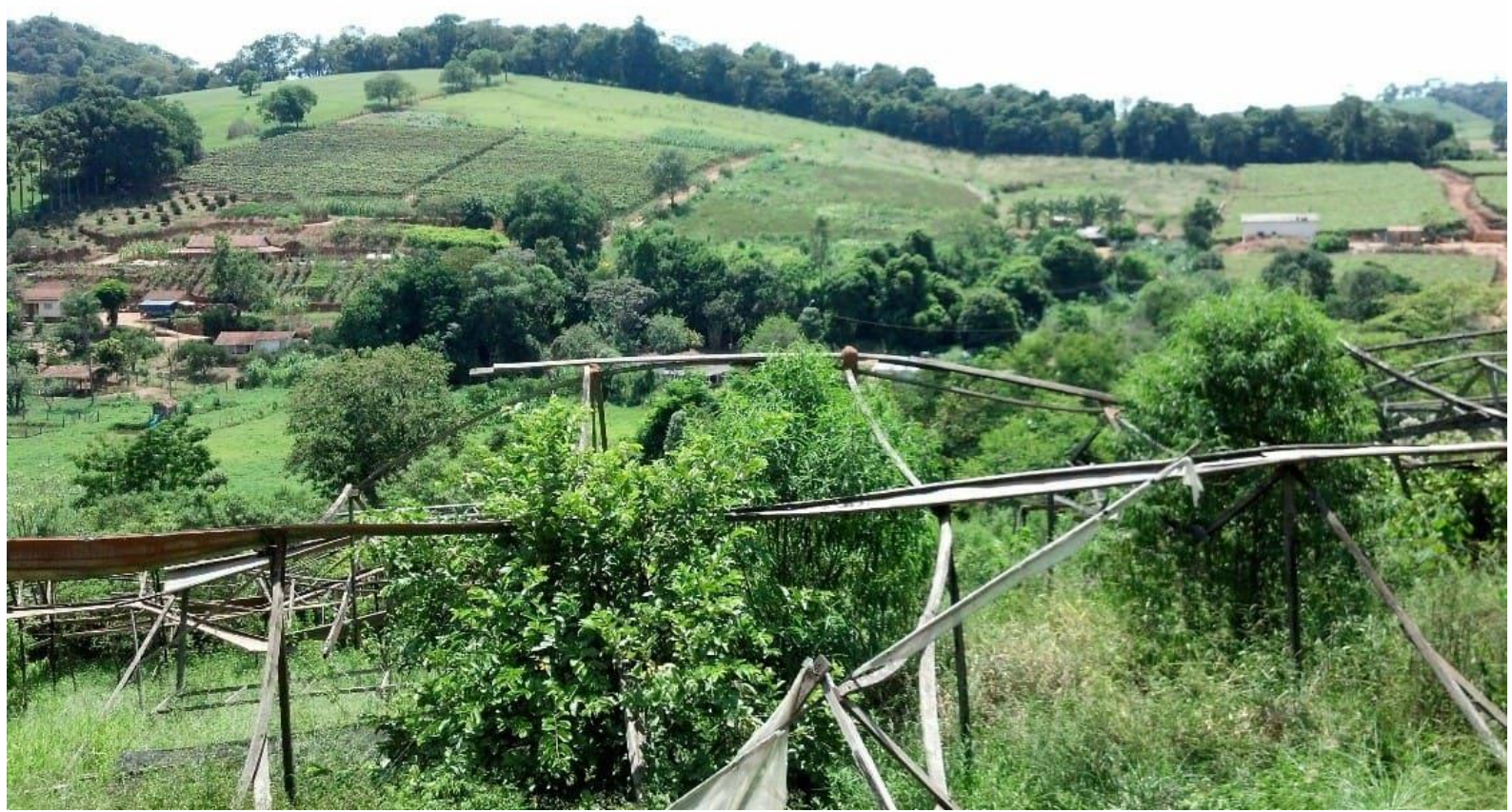

Fonte - Foto pessoal do autor, 2015.

Disponível em: https://www.nucleodoconhecimento.com.br/arquitetura/bioclimatologia 


\subsubsection{ANTEPROJETO}

Foi elaborado o anteprojeto arquitetônico com o software AutoCAD, deste modo, feitas três plantas baixas e duas fachadas, a planta baixa do pavimento térreo (Figura 17), do superior (Figura 18), da cobertura (Figura 19) e fachada frontal (Figura 20) e lateral (Figura 21).

Figura 17 - Planta baixa do pavimento térreo com a delimitação do norte e marcação do terreno.

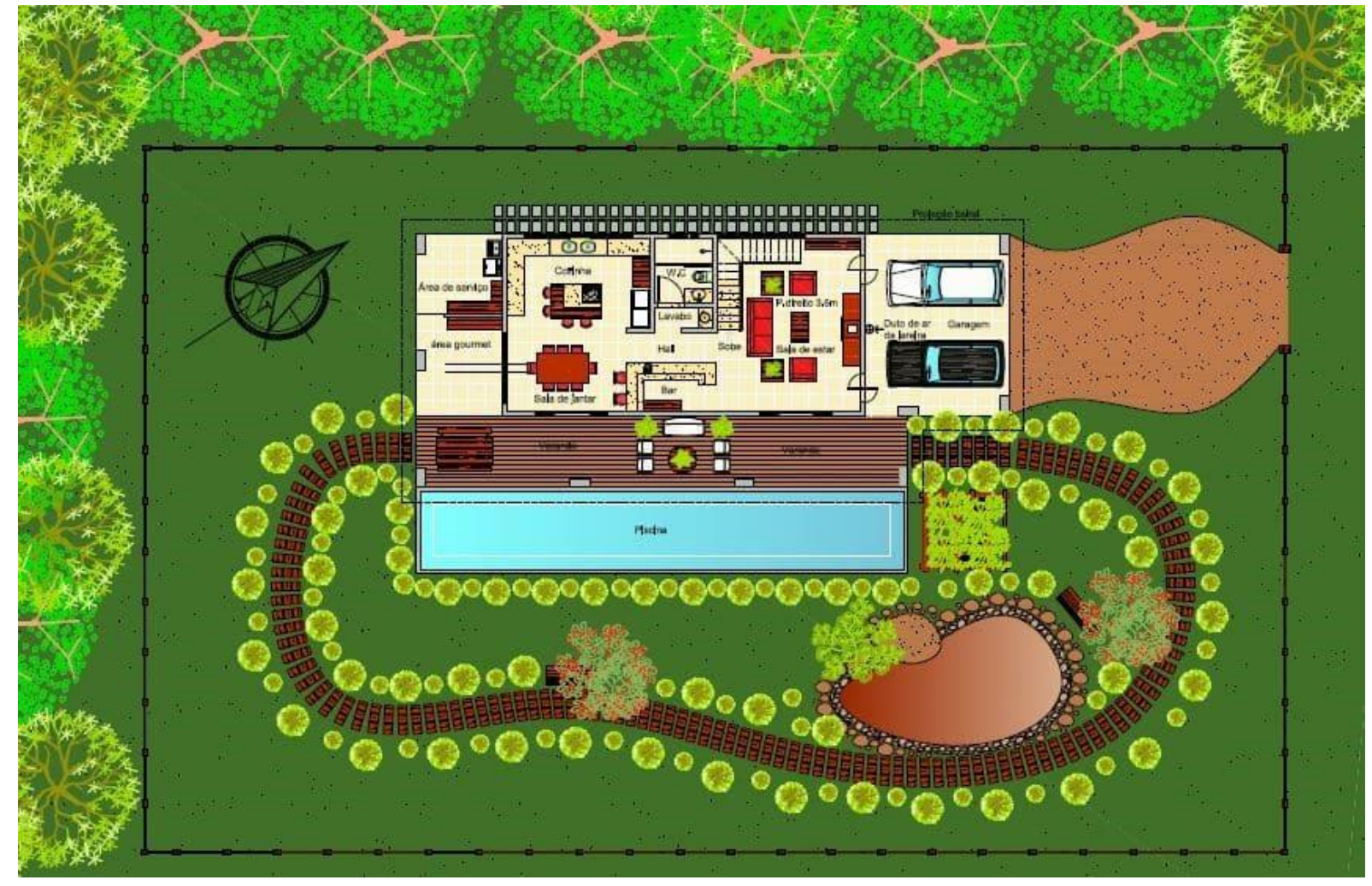

Fonte - Arquivo pessoal do autor realizado pelo software AutoCAD, 2015. 
Figura 18 - Planta baixa do pavimento superior com a delimitação do norte e da mata fechada.
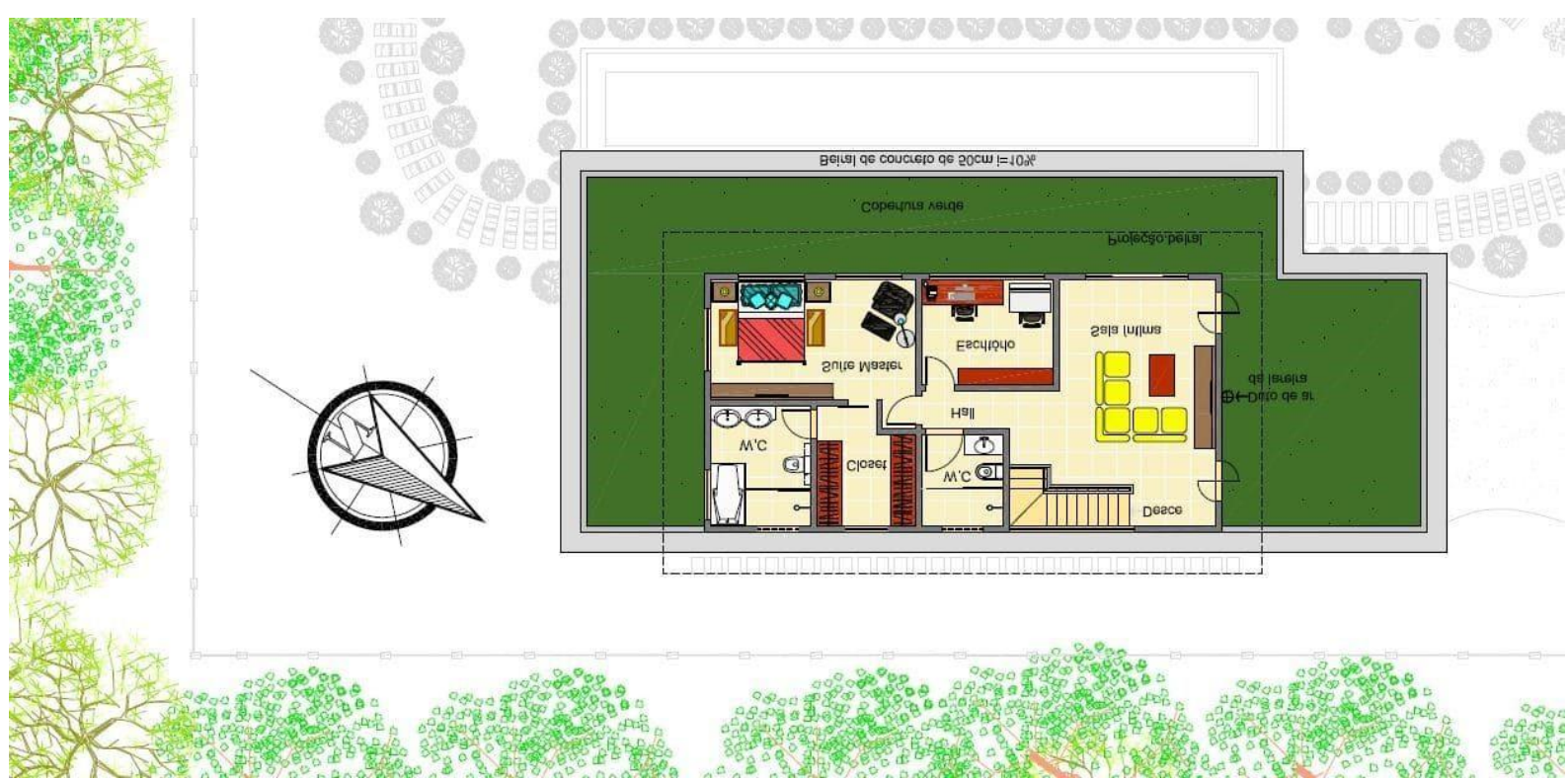

Fonte - Arquivo pessoal do autor realizado pelo software AutoCAD, 2015.

Figura 19 - Planta baixa de cobertura com a delimitação do norte e da mata fechada.

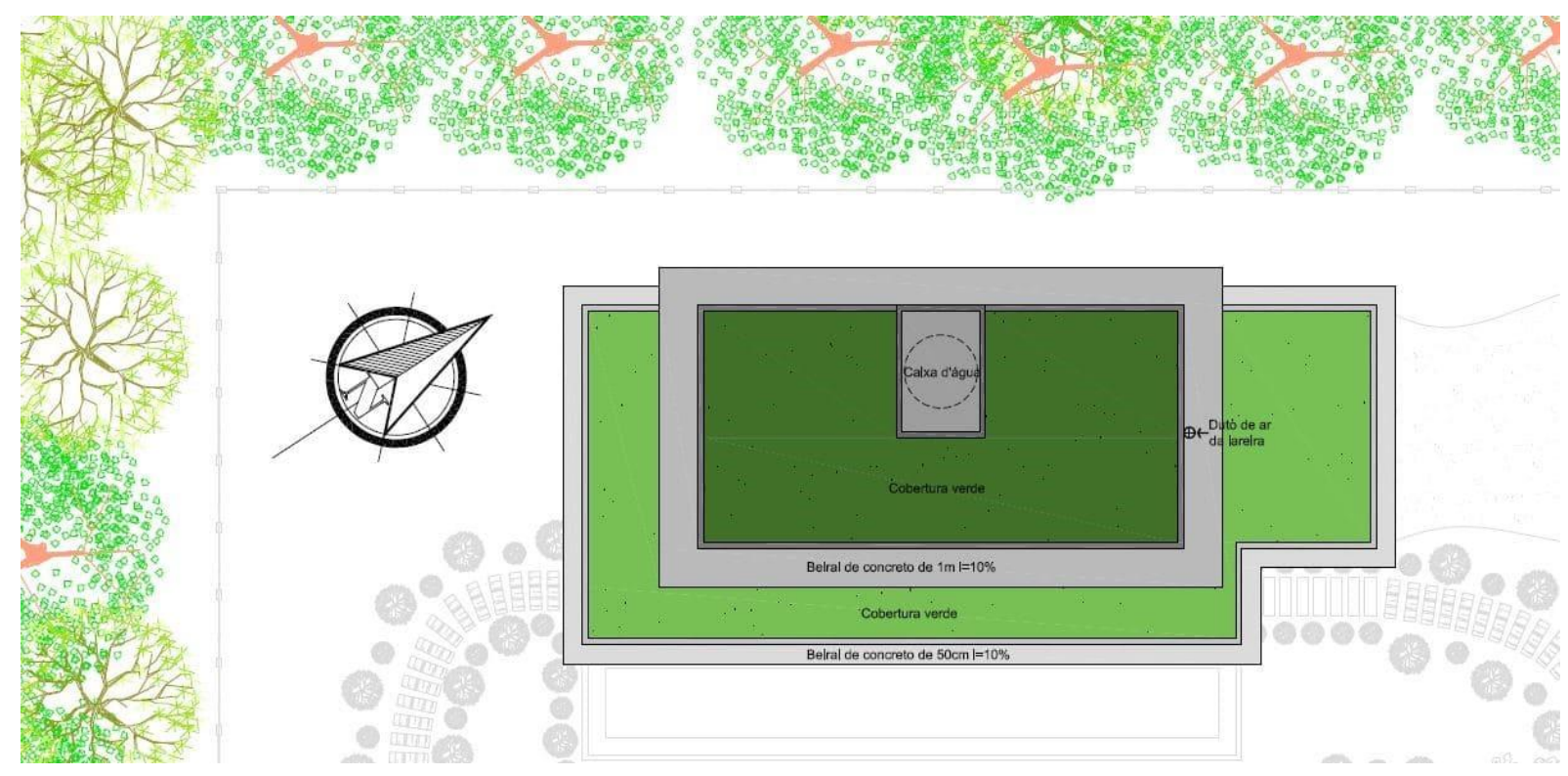

Fonte - Arquivo pessoal do autor realizado pelo software AutoCAD, 2015. 
Figura 20 - Fachada frontal.

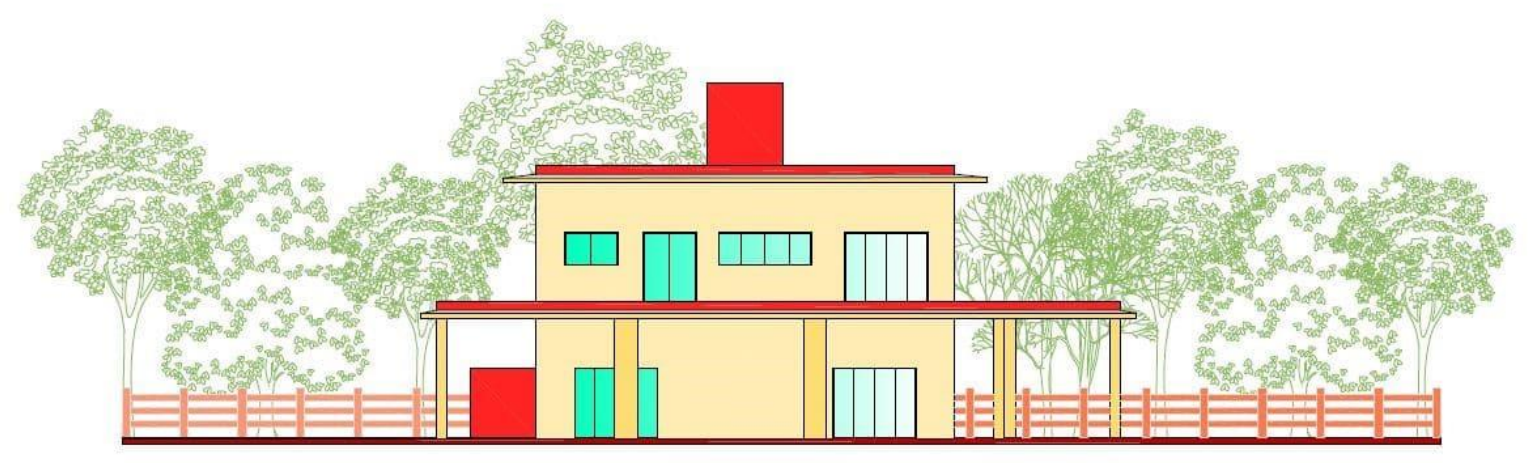

Fonte - Arquivo pessoal do autor realizado pelo software AutoCAD, 2015.

Figura 21 - Fachada lateral.

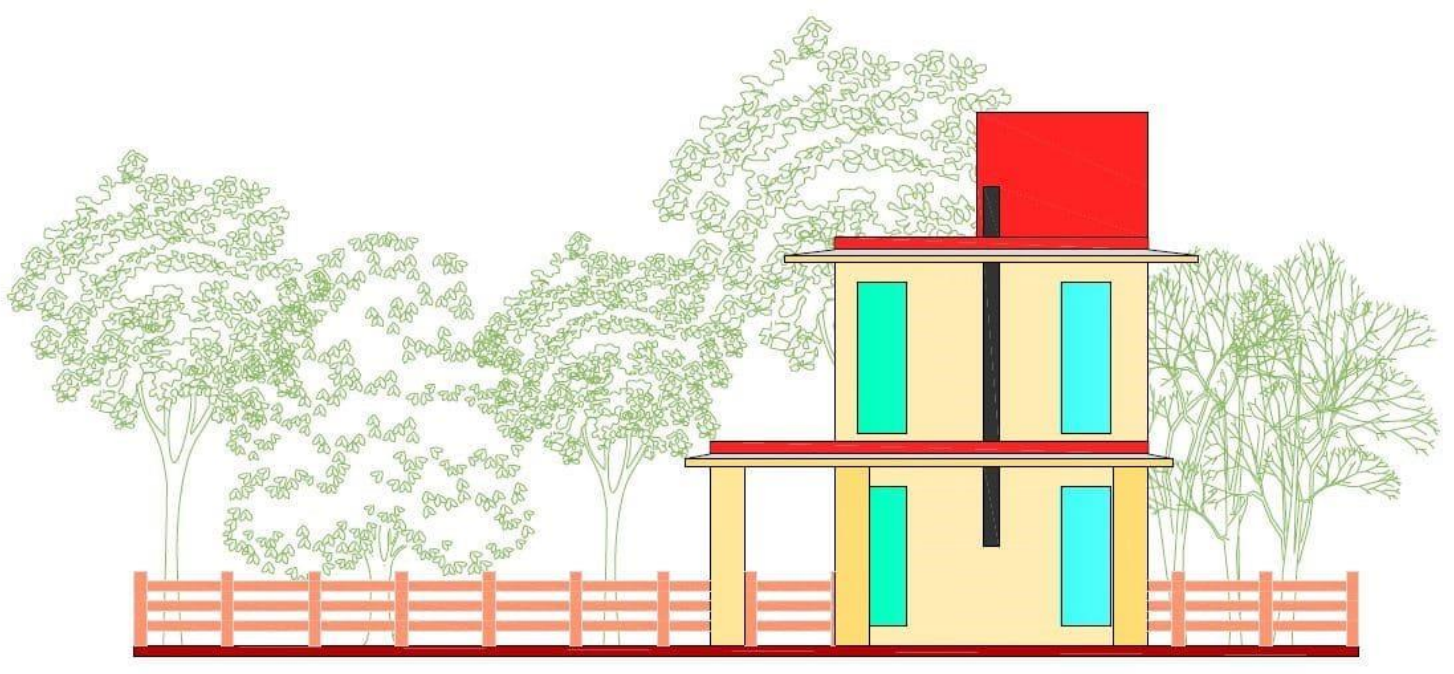

Fonte - Arquivo pessoal do autor realizado pelo software AutoCAD, 2015.

\subsubsection{ANTEPROJETO ARQUITETÔNICO E SUAS ESTRATÉGIAS BIOCLIMÁTICAS PARA O INVERNO}

O anteprojeto foi realizado em cima de todas as estratégias bioclimáticas estudadas para a região de Atibaia. Aplicando no projeto as três estratégias para o inverno, tais como, as vedações internas das paredes, aquecimento solar da edificação e permitir 
insolação dos ambientes, a vedação interna das paredes foi projetada como pede a norma NBR 15220 para esta região, ficando deste modo, com 15 centímetros devido a escolha desta parede (Tabela 8).

Tabela 8 - Parede selecionada para o anteprojeto arquitetônico.

\begin{tabular}{|c|c|c|c|c|}
\hline Parede & Descrição & $\begin{array}{c}U \\
{[\mathbf{W} /(\mathbf{m} 2 . K)]}\end{array}$ & $\begin{array}{c}\mathrm{CT} \\
{[\mathrm{kJ} /(\mathrm{m} 2 . \mathrm{K})]}\end{array}$ & $\begin{array}{c}\varphi \\
\text { [horas] }\end{array}$ \\
\hline & $\begin{array}{l}\text { Parede de tijolos maciços, } \\
\text { assentados na menor } \\
\text { dimensão. } \\
\text { Dimensões do tijolo: } \\
\text { 10,0x6,0x } 22,0 \mathrm{~cm} . \\
\text { Espessura da argamassa de } \\
\text { assentamento: } 1,0 \mathrm{~cm} . \\
\text { Espessura da argamassa de } \\
\text { emboço: } 2,5 \mathrm{~cm} . \\
\text { Espessura total da parede: } \\
15,0 \mathrm{~cm} .\end{array}$ & 3,13 & 255 & 3,8 \\
\hline
\end{tabular}

Fonte: Arquivo pessoal do autor elaborada a partir da NBR 15220-3.

Quanto a estratégia de "aquecimento solar da edificação", o anteprojeto foi planejado para que a edificação tenha o aquecimento solar direto, permitindo a entrada diretamente ao interior dos ambientes da radiação solar, através de aberturas de portas balcão (PB) e de janelas de correr (JC), basculantes (JB) e pivotantes (JP), ambas em vidro, gerando deste modo, o "efeito estufa". No pavimento térreo (Figura 22), tem duas portas balcão na sala de jantar e uma na sala de estar, está sendo, a entrada principal da casa. Possui também três janelas basculantes e duas pivotantes, sendo as basculantes, uma na cozinha, uma no banheiro e uma na escada e as pivotantes, as duas na sala de estar.

Em tempos de inverno, devem-se deixar as janelas e portas o mínimo abertas possíveis, para que este calor não escape dos ambientes. 
Figura 22 - Planta baixa do pavimento térreo e suas aberturas.

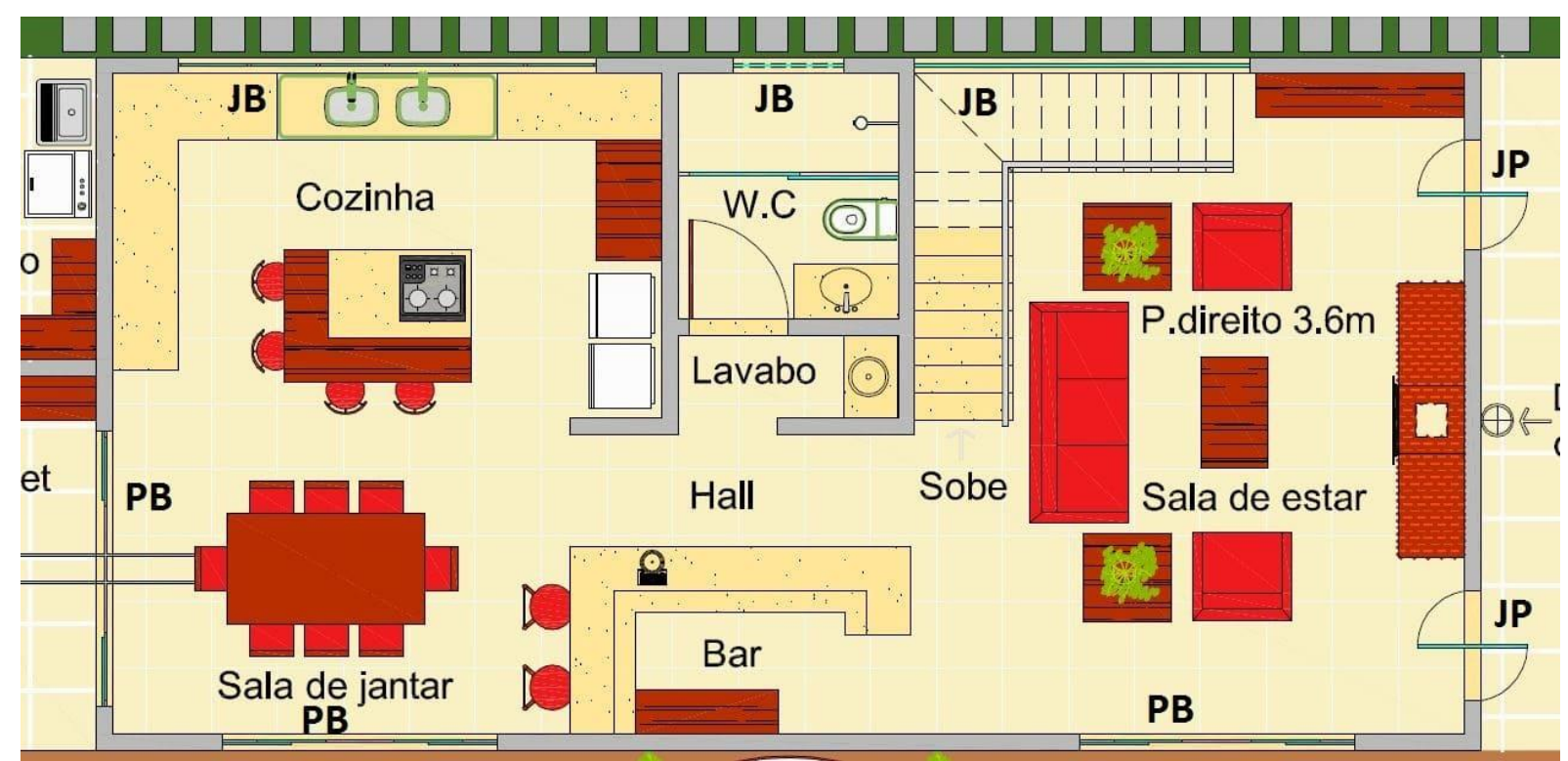

Fonte - Arquivo pessoal do autor realizado pelo software AutoCAD, 2015.

Já no pavimento superior (Figura 23), quanto às aberturas para uma radiação solar interna, existem duas portas balcão, sendo uma na suíte máster e uma na sala íntima, ambas dando acesso à cobertura verde que também faz função de varanda. Quanto às janelas, há duas de correr na suíte máster e uma no escritório, cinco janelas basculantes, sendo duas no banheiro da suíte máster, uma no closet e no banheiro do hall e uma na escada. Por fim, existem duas janelas pivotantes na sala íntima, todas contribuindo para um aquecimento solar direto. 
Figura 23 - Planta baixa do pavimento superior e suas aberturas.

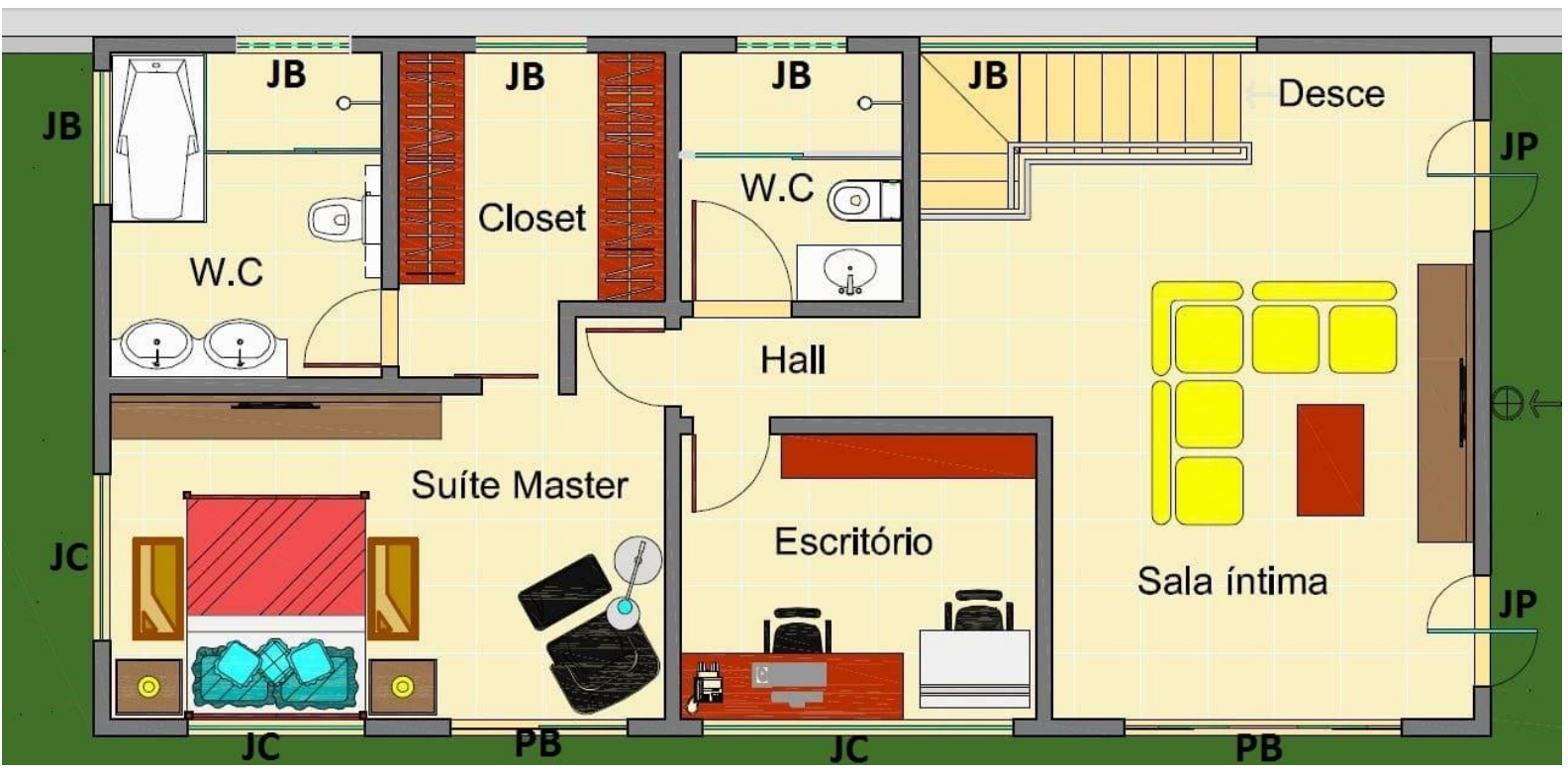

Fonte - Arquivo pessoal do autor realizado pelo software AutoCAD, 2015.

Na estratégia de "permitir insolação dos ambientes", através da Carta Solar realizada pelo software Analysis-BIO, nota-se que o sol, se faz necessário e não necessário, em determinada época do ano, sendo a principal diferença desta estratégia para a de "aquecimento solar da edificação". Na ocasião deste projeto, devido ao lado oeste e sul ser servido de mata alta e fechada (Figura 13), o sol do lado leste (sol mais quente), após as 15 horas não incide mais na edificação.

Visto este acontecimento, foi realizado em quantidades e tamanhos maiores em um total de dez aberturas no lado leste, norte e nordeste da edificação para a insolação dos ambientes, como mostra as figuras 22 e 23 . No inverno, o trajeto solar tende ser mais ao norte ao meio dia como mostra na figura 8 , neste caso, foi projetado duas aberturas de janelas pivotantes (JP) do piso ao teto na sala de estar, dando continuidade a sala íntima do pavimento superior, para a entrada destes raios solares essenciais no inverno (Figura 24).

O importante ressaltar que mesmo atendendo a insolação para o inverno, estas mesmas aberturas possuem grandes beirais para o verão, e a vegetação faz a sua 
parte de sombreamento no lado oeste, já que neste período do ano no verão, os raios solares incidem bem menos na fachada norte como mostra a figura 8 .

Para exemplificar a insolação com mais nitidez, foi realizado uma perspectiva no software SketchUp Make, onde é capaz de produzir o sol na edificação com exatidão de posicionamento quanto aos meses, dias e horas do ano, deste modo, a edificação foi locada no posicionamento correto quanto aos pontos colaterais e cardeais. As figuras 25 e 26 mostram a incidência do sol no inverno na edificação onde se faz necessário para um bom aquecimento neste período do ano.

Figura 24 - Entrada solar nas janelas pivotantes no período de inverno.

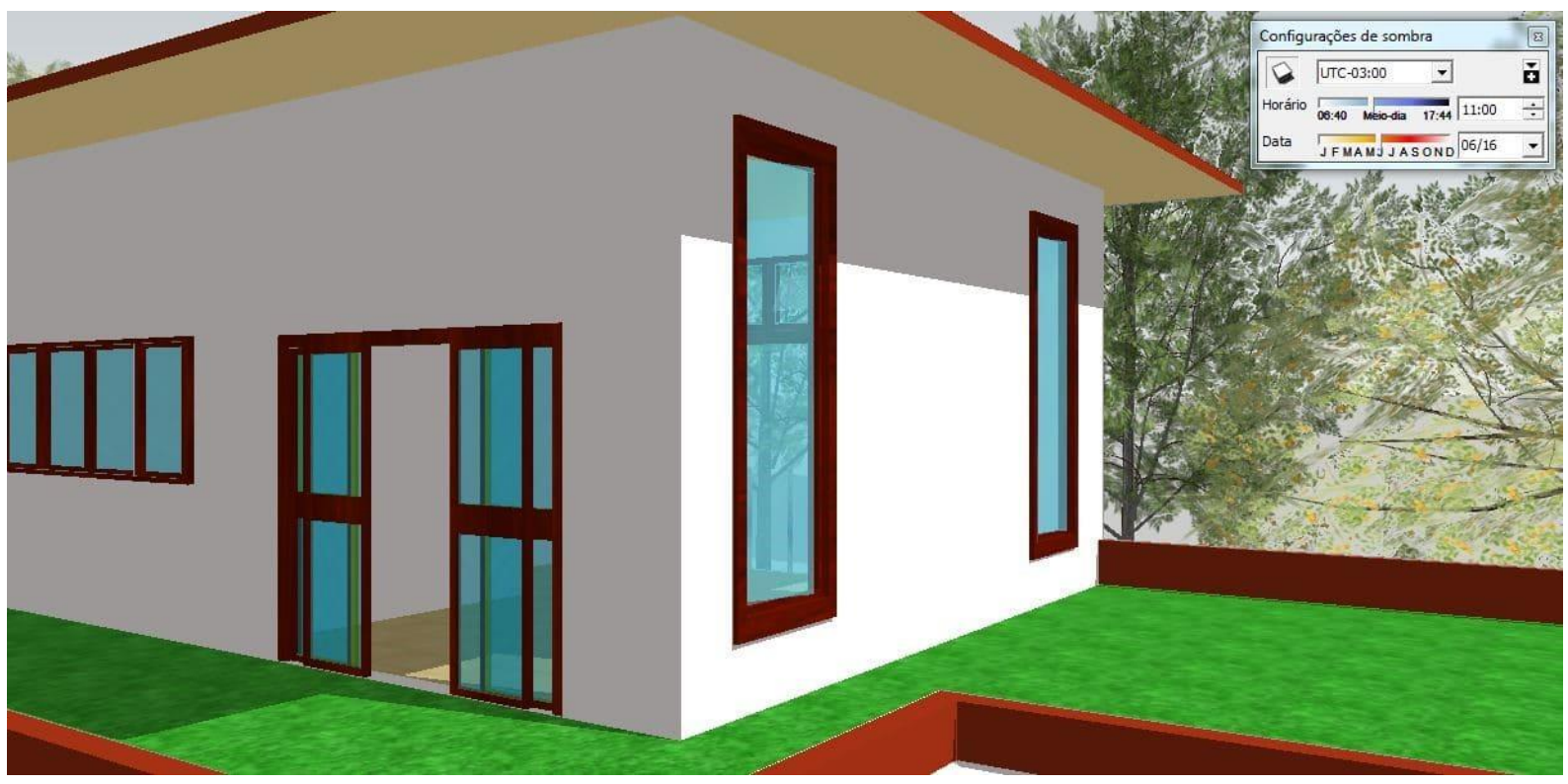

Fonte - Perspectiva realizada pelo autor com o software SketchUp Make. 
Figura 25 - Incidência do sol no lado leste da edificação no período de inverno pela manhã.

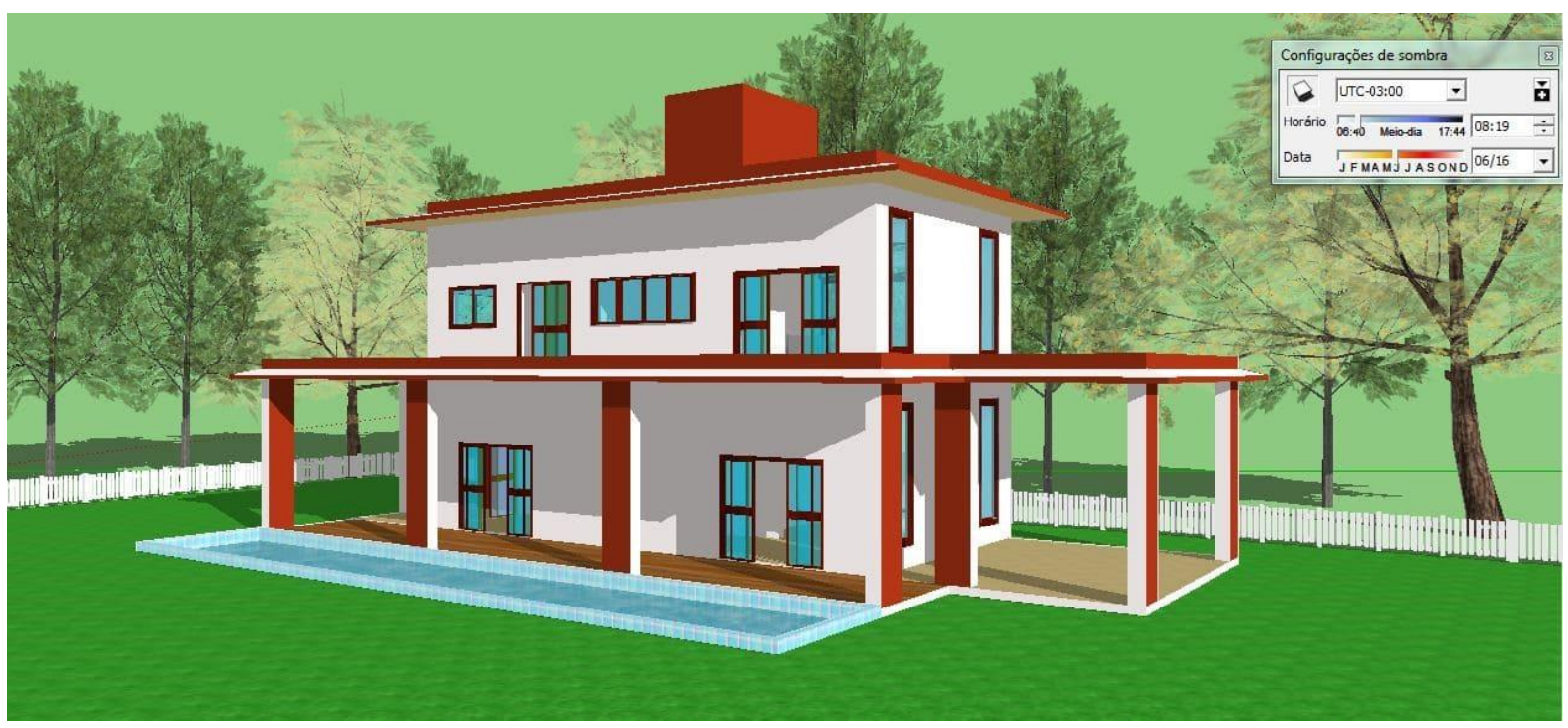

Fonte - Perspectiva realizada pelo autor com o software SketchUp Make.

Figura 26 - Incidência do sol no lado oeste da edificação no período de inverno pela tarde.

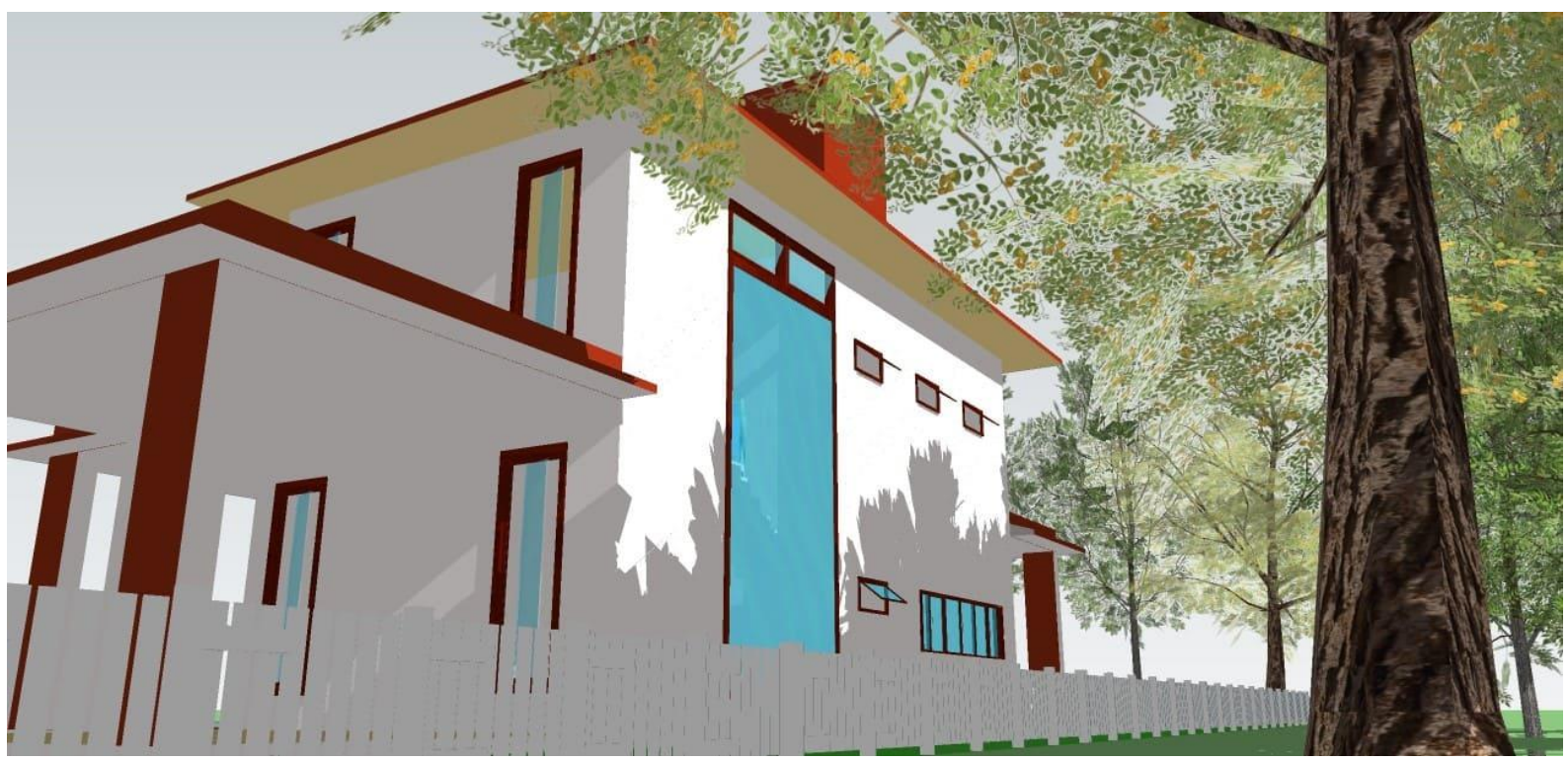

Fonte - Perspectiva realizada pelo autor com o software SketchUp Make. 


\subsubsection{ANTEPROJETO ARQUITETÔNICO E SUAS ESTRATÉGIAS BIOCLIMÁTICAS PARA O VERÃO}

A estratégia bioclimática planejada no anteprojeto para o verão foi a "ventilação cruzada". Através da direção do Norte, podemos saber a direção da ventilação no terreno e assim realizar um projeto mais eficaz quanto a esta estratégia. Para ser mais exato, foi utilizado o software Analysis SOL-AR, onde ele mostra por capitais, as rosas dos ventos quanto a frequência de ocorrência e quanto a velocidade de predominância dos ventos. Estas rosas dos ventos (Figura 27 e 28), são da cidade de São Paulo que possui a mesma zona bioclimática 3 de Atibaia, neste caso, pode ser utilizada para tanto.

Através da rosa dos ventos (Figura 27), pode-se notar que no período da primavera e do outono as maiores frequências de ocorrência dos ventos são do sentido sudeste, e no período do inverno a predominância é no sentido nordeste, e por fim, no verão a predominância é um pouco mais no nordeste, mas também ocorrendo com frequência no norte, sudeste e sul. De acordo com a rosa dos ventos (Figura 28), na primavera e no inverno, os ventos mais fortes estão no sentido sudeste, no outono no sentido sul e no verão a velocidade predominante é igual para todos os sentidos.

Figura 27 - Rosa dos ventos para São Paulo quanto a frequência de ocorrência.

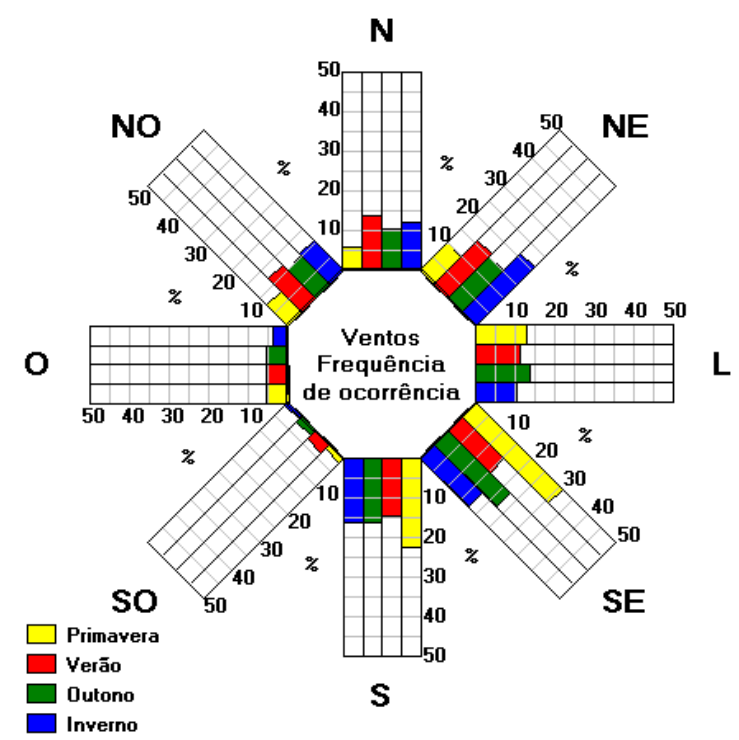

RC: 52839

Disponível em: https://www.nucleodoconhecimento.com.br/arquitetura/bioclimatologia 
Fonte - Arquivo pessoal do autor extraída do Software Analysis SOL-AR, 2015.

Figura 28 - Rosa dos ventos para São Paulo quanto a predominância por direção.

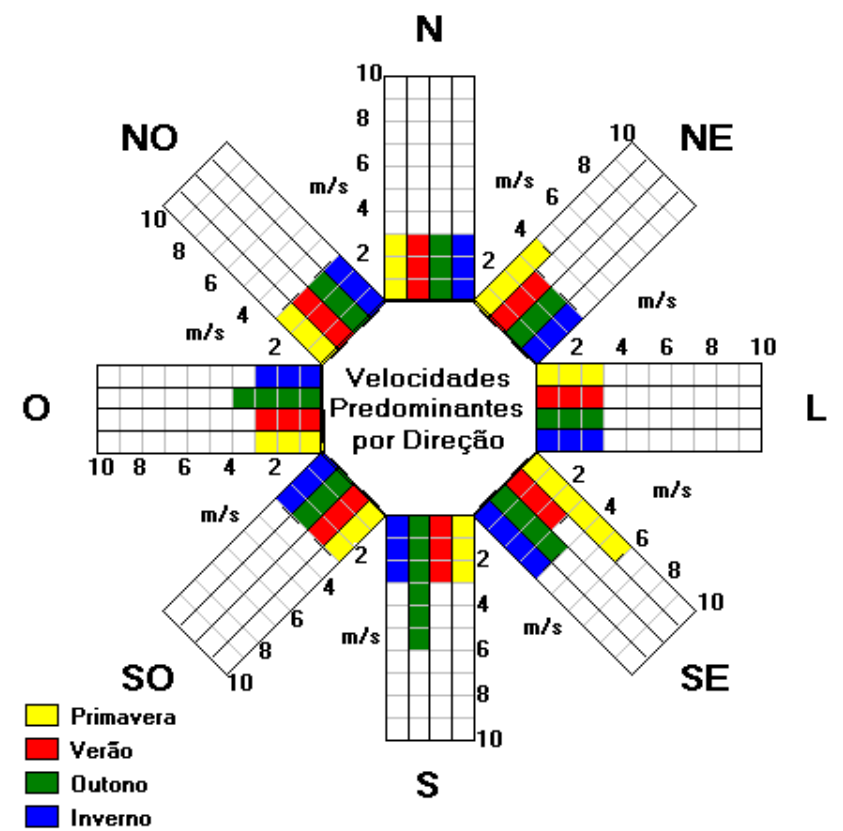

Fonte - Arquivo pessoal do autor extraída do Software Analysis SOL-AR, 2015.

Através destas rosas dos ventos pôde-se realizar e planejar as aberturas ideais para o verão, para que tenha a ventilação cruzada fazendo com que os ambientes internos fiquem agradáveis nesta época do ano. Todas as aberturas das salas de estar e jantar estão voltados ao nordeste, leste e sudeste, onde tem predominância de ventos no verão (Figura 29 e 30). 
Figura 29 - Planta baixa térreo quanto a predominância de ventos por direção.

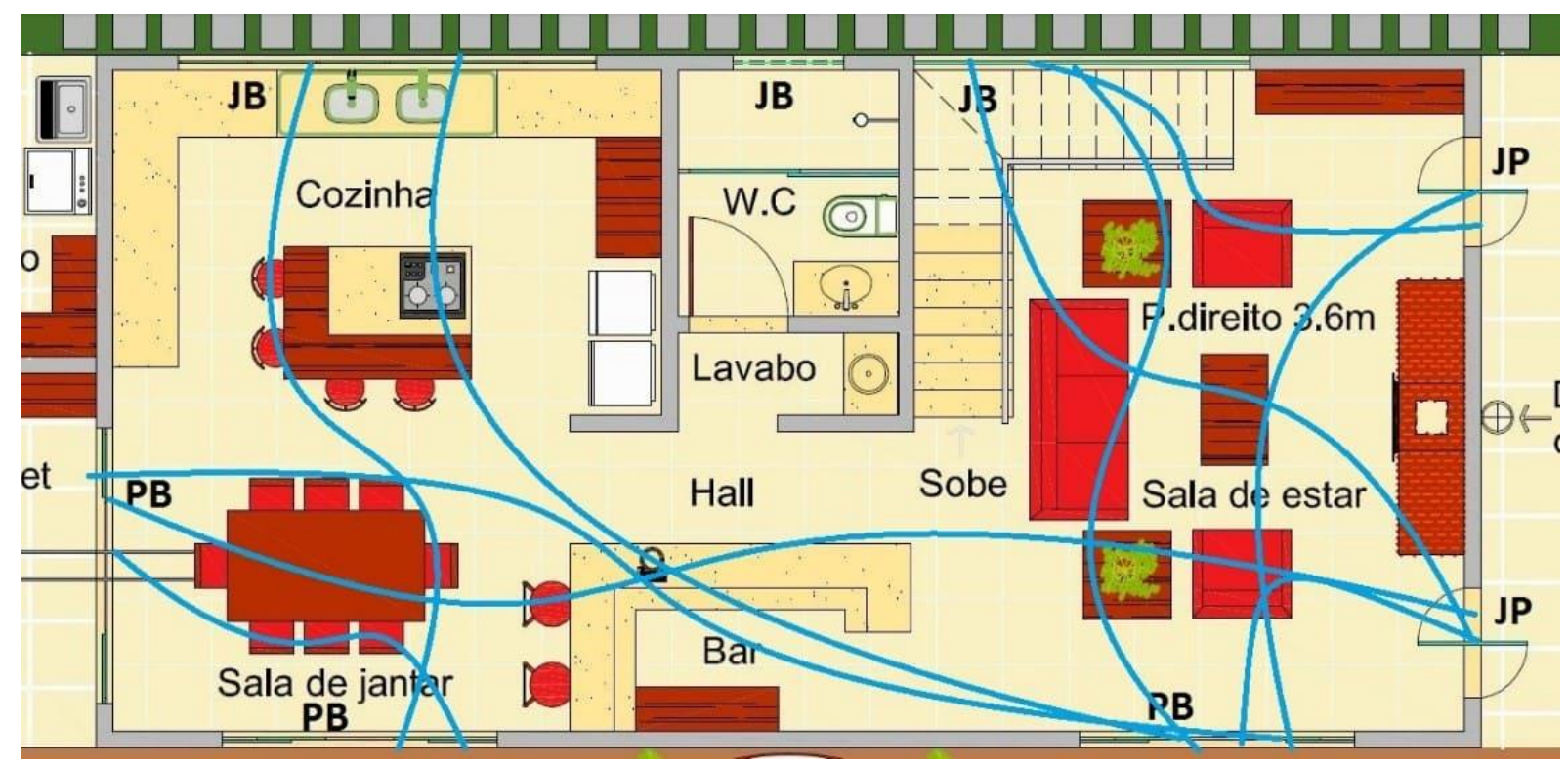

Fonte - Arquivo pessoal do autor realizado pelo software AutoCAD, 2015.

A suíte master, o banheiro e a sala íntima, possuem as ventilações cruzadas necessárias para um bom ambiente interno.

Figura 30 - Planta baixa superior quanto a predominância de ventos por direção.

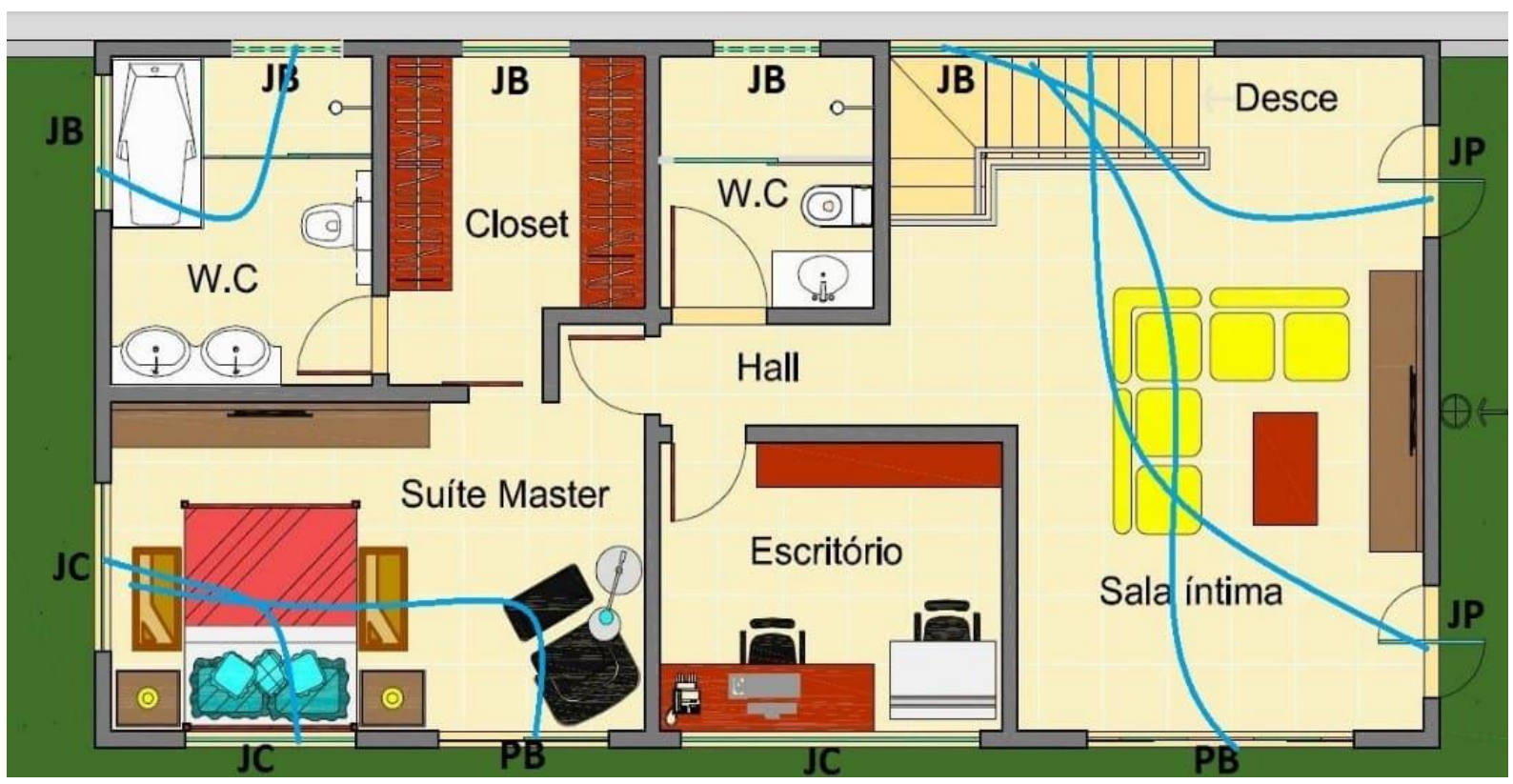

Fonte - Arquivo pessoal do autor realizado pelo software AutoCAD, 2015. 
Mesmo atendido todas as exigências da norma NBR 15220-3 no anteprojeto, foram adicionados alguns detalhes a mais para deixar o projeto ainda mais confortável aos seus usuários. A cobertura verde é uma maneira perfeita para atender este tipo de ocasião. Ela melhora o conforto térmico dos edifícios, funciona como retardador de fluxo de calor reduz a transmissão de ruídos para dentro do edifício e o escoamento da água de chuva, reoxigena o ar e remove toxinas (através das plantas da cobertura), filtra a água para ser armazenada e utilizada (a própria camada de plantas e terra atua como filtro) e por fim, promove mais um ambiente para os usuários do edifício, podendo utilizar este ambiente da cobertura como uma varanda, como ocorre neste presente estudo de anteprojeto (Figura 31). Fato importante a citar, que estas estratégias de ventilação no verão e de iluminação e aquecimento no inverno, terá como consequência, uma economia de energia em toda a edificação.

Figura 31 - Planta baixa superior e sua cobertura verde em forma de varanda.

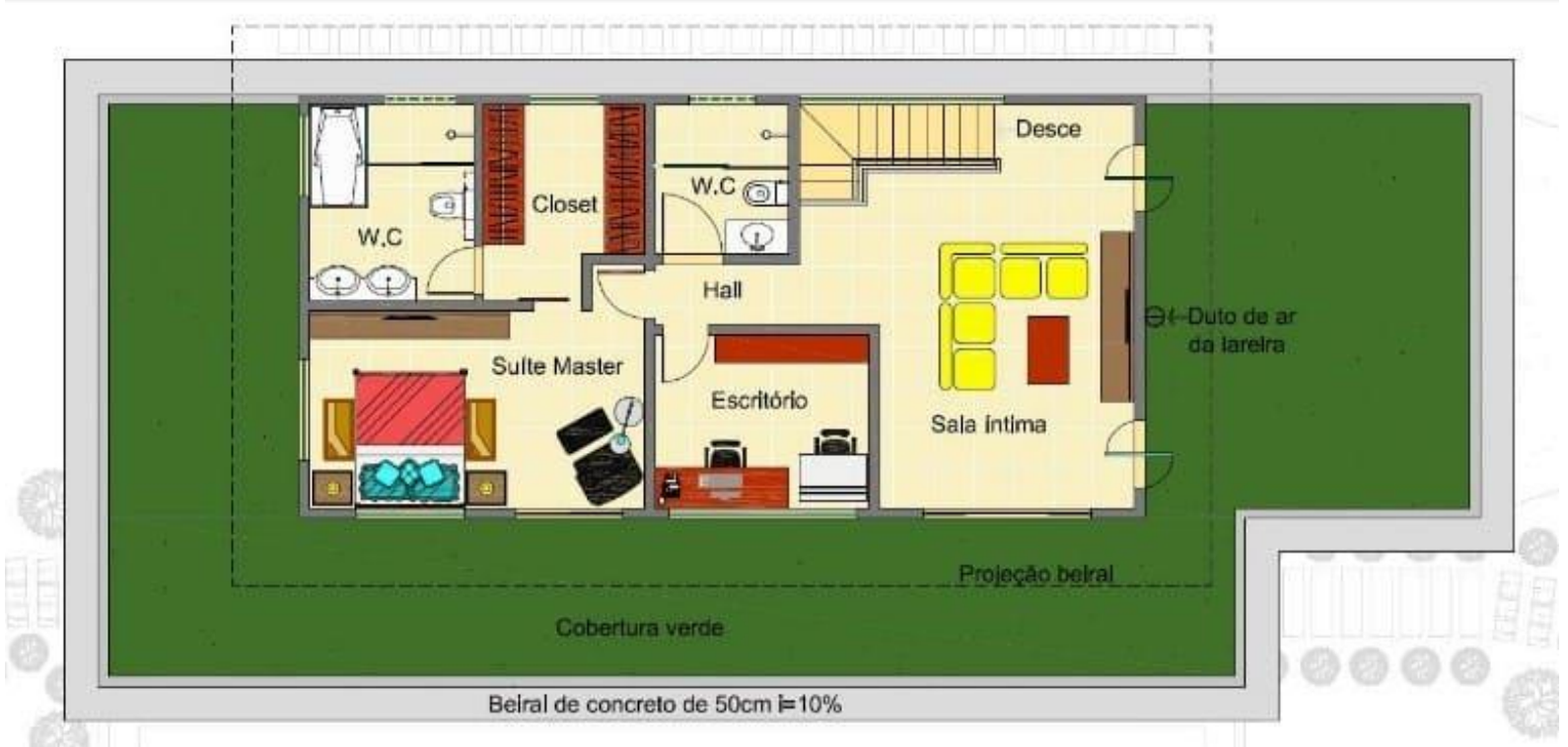

Fonte - Arquivo pessoal do autor realizado pelo software AutoCAD, 2015.

\section{CONSIDERAÇÕES FINAIS}

Através do estudo da NBR 15220-3, com a ajuda dos dados dos softwares utilizados, foram aplicadas e discutidas estratégias bioclimáticas para a cidade de Atibaia. Os resultados da aplicação de tais estratégias foram benéficas e positivas, trazendo mais 
conforto ambiental aos usuários em todas as estações, principalmente no verão e no inverno, períodos/épocas em que é necessária maior atenção ao tema.

Nos dias de hoje, a arquitetura bioclimática está cada vez mais mostrando sua importância nos processos de planejamento de uma edificação, integralizando o homem ao meio ambiente e consequentemente Ihe proporcionando mais qualidade de vida e bem estar. Neste caso, o arquiteto se torna essencial dentro do processo de projeto, pois é através dele, que a maior parte das decisões tomadas vão influenciar no desempenho final do edifício.

Por tanto, mostra-se que um projeto bioclimático é um estudo multidisciplinar, apresentando uma série de variáveis nos aspectos de uma edificação. O presente trabalho, frente ao que foi estudado, há muito o que ser descoberto e pesquisado. É necessário que os profissionais desta área, trabalhem juntos para que possam obter mais resultados construtivos, fazendo com que, os projetos arquitetônicos atendam ainda mais as estratégias bioclimáticas para a cidade de Atibaia.

\section{REFERÊNCIAS}

AGOPYAN, Vahan; JOHN, Vanderley. O Desafio da Sustentabilidade na Construção Civil. São Paulo: Blucher, 2012.

ANDRADE, Suely. Estudos de estratégias bioclimáticas no clima de florianópolis. 129 p. 1996. Dissertação (Mestrado) - Universidade Federal de Santa Catarina, Florianópolis, 1996.

ASSOCIAÇÃO BRASILEIRA DE NORMAS TÉCNICAS (ABNT). NBR 15220-3 Desempenho térmico de edificações. Rio de Janeiro, 2005.

CENTRO DE PESQUISA METEREOLÓGICAS E CLIMATICAS APLICADAS A AGRICULTURA - CEPAGRI. Clima dos Municípios Paulistas. Atibaia. Disponível em:

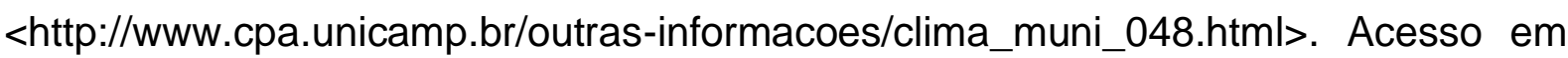
20 abr. 2015. 
EMPRESA BRASILEIRA DE PESQUISA AGROPECUÁRIA - EMBRAPA. Banco de Dados Climáticos do Brasil. Resultados. Atibaia. Disponível em: < http://www.bdclima.cnpm.embrapa.br/resultados/balanco.php?UF=\&COD=255>. Acesso em 22 abr. 2015.

FUENTES, Manuel; THOMAS, Stephanie. EcoHouse: A Casa Ambientalmente Sustentável. 2.ed. Porto Alegre: Artmed, 2006.

KEELER, Marian; BURKE, Bill. Fundamentos de Projeto de Edificações Sustentáveis. Porto Alegre: Artmed, 2010.

LABORATÓRIO DE EFICIENCIA ENERGÉTICA EM EDIFICAÇÕES - LABEEE. Downloads. Softwares. Disponível em:

http://www.labeee.ufsc.br/downloads/softwares>. Acesso em 25 abr. 2015.

LAMBERTS, Roberto; DUTRA, Luciano; PEREIRA, Fernando. Eficiência Energética na Arquitetura. 3.ed. Santa Catarina. 2008.

MONTAGNER, Juliana; SACHT, Helenice. Estratégias bioclimáticas para edifícios destinados ao clima da cidade de Araras - SP. In: VI CONGRESSO DE INICIAÇÃO CIENTÍFICA DO CENTRO UNIVERSITÁRIO DE ARARAS "DR. EDMUNDO ULSON" - UNAR. 6, 2013a, Araras. Anais...Araras, UNAR. n. 13.

OLIVEIRA, Edmundo. Metodologia do Trabalho Científico. In UNIARA, Araraquara. Disponível em:

http://ead.uniaraonline.com.br/moodle/mod/resource/view.php?inpopup=true\&id=737 09>. Acesso em 01 de maio. 2015.

\section{APÊNDICE - REFERÊNCIAS DE NOTA DE RODAPÉ}

3. (https://www.infoescola.com/geografia/classificacao-climatica-de-koppen-geiger/ Acesso em 30 abril 2015).

Enviado: Maio, 2020. 
Aprovado: Junho, 2020. 